\title{
Vein graphite deposits: geological settings, origin, and economic significance
}

\author{
F. J. Luque \& J-M. Huizenga \& E. Crespo-Feo \& H. Wada \& L. Ortega \& J. F. Barrenechea
}

\author{
F. J. Luque $\cdot$ E. Crespo-Feo $\cdot$ L. Ortega $\cdot$ J. F. Barrenechea \\ Departamento Cristalografía y Mineralogía, Facultad de Geología, Universidad Complutense de Madrid, 28040 Madrid, Spain \\ F. J. Luque $(*):$ J. F. Barrenechea \\ Instituto de Geociencias (UCM, CSIC), José Antonio Novais 12, 28040 Madrid, Spain. e-mail: jluque@geo.ucm.es \\ J.M. Huizenga \\ Unit of Environmental Sciences and Development, North-West. University, Potchefstroom, South Africa \\ J.M. Huizenga \\ Economic Geology Research Unit (EGRU), School of Earth and Environmental Sciences, James Cook University, Townsville 481 1, Australia \\ H. Wada \\ Department of Geosciences, Shizuoka University, 836 Oya, Suruga-Ku, Shizuoka 422-8529, Japan
}

\begin{abstract}
Graphite deposits result from the metamorphism of sedimentary rocks rich in carbonaceous matter or from precipitation from carbon-bearing fluids (or melts). The latter process forms vein deposits which are structurally controlled and usually occur in granulites or igneous rocks. The origin of carbon, the mechanisms of transport, and the factors control-ling graphite deposition are discussed in relation to their geological settings. Carbon in granulite-hosted graphite veins derives from sublithospheric sources or from decarbonation reactions of carbonate-bearing lithologies, and it is transported mainly in $\mathrm{CO}_{2}$-rich fluids from which it can precipitate. Graphite precipitation can occur by cooling, water removal by retrograde hydration reactions, or reduction when the $\mathrm{CO}_{2}$-rich fluid passes through relatively low- $\mathrm{fO}_{2}$ rocks. In igneous settings, carbon is derived from assimilation of crustal mate-rials rich in organic matter, which causes immiscibility and the formation of carbon-rich fluids or melts. Carbon in these igneous-hosted deposits is transported as $\mathrm{CO}_{2}$ and/or $\mathrm{CH}_{4}$

and eventually precipitates as graphite by cooling and/or by hydration reactions affecting the host rock. Independently of the geological setting, vein graphite is characterized by its high purity and crystallinity, which are required for applica-tions in advanced technologies. In addition, recent discovery of highly crystalline graphite precipitation from carbon-bearing fluids at moderate temperatures in vein deposits might provide an alternative method for the manufacture of synthetic graphite suitable for these new applications.
\end{abstract}

Keywords Graphite $\cdot$ Vein deposits $\cdot$ Carbon-bearing fluids $\cdot$ Granulites $\cdot$ Igneous rocks $\cdot$ Carbon cycle

\section{Introduction}

Graphite, pure carbon, has a simple composition and a quite simple layered structure. However, interesting physical properties make graphite a very important industrial mineral with many applications including a group of new and developing technologies such as lithium-ion batteries, nuclear, wind and solar power, fuel cells, semi-conductors, or even graphene (Crossley 2000; Balan et al. 2010). Thus, natural graphite has been recently considered by the United States and the European Union a supply-critical mineral. For example, in 2010, the British Geological Survey ranked graphite right behind the rare earths and substantially ahead of lithium in terms of supply criticality.
Graphite deposits result from the conversion of carbonaceous matter through contact or regional metamorphism or by deposition from carbon-bearing fluids (or, less commonly, melts). The former process forms syngenetic deposits that yield either amorphous and flake graphite, depending on the metamorphic grade of the host rock (Mitchell 1993). Flake graphite usually occurs in high-grade gneisses, quartzites, or granulite facies rocks. The second process forms epigenetic, 
vein deposits in which lump graphite occur (Mitchell 1993). Amorphous, flake, and lump graphite are commercial terms to designate cryptocrystalline $(<70 \mu \mathrm{m})$, crystalline, and coarsely crystalline graphite, respectively.

Syngenetic graphite deposits are usually stratabound with tabular, lenticular, or irregular ore bodies. In these occurrences, graphite results from the progressive transformations that carbonaceous matter undergoes through prograde metamorphic conditions. This process is usually referred to as graphitization (Kwiecinska and Petersen 2004). The changes induced by metamorphism on the carbonaceous matter include both structural and chemical modifications which begin during the earlier stages of diagenesis. The product grade of graphite from these deposits varies widely with the amount of mineral impurities, ranging from $75 \%$ to $97 \%$ carbon.

Epigenetic graphite deposits provide the chemically purest graphite, with carbon contents around $99 \%$ in the graphite concentrates. They are usually hosted by high-grade metamorphic rocks (mainly granulites) and by acid to ultrabasic igneous rocks, including both plutonic and volcanic (Luque et al. 1998).

The aim of this paper is to present a comprehensive review of the occurrences of vein graphite deposits, integrating their features with the geological settings and the factors controlling the mineralizing processes. The mineralogical characteristics of graphite in these deposits will be related to their potential industrial applications.

\section{Geological settings}

Vein graphite deposits are structurally controlled as they result from deposition from carbon-bearing fluids (or melts) that are channelled through fracture systems. Therefore, these deposits record the transport of carbon through the crust and mantle. Carbon-bearing fluids and melts have been recognized in a wide diversity of geological settings. However, vein graphite deposits are restricted to granulite facies terranes and to igneous rocks. The characteristics of graphite occurrences in both settings show significant differences in terms of the style of the ore bodies, mineralogy, origin of the carbon, and mechanisms of graphite deposition. Thus, in the following sections, we will examine the characteristics of graphite deposits for each geological setting. The world distribution of vein graphite deposits and occurrences is shown in Fig. 1.

\section{Granulite-hosted deposits}

Most of the granulite-hosted vein graphite deposits occur in rocks of Precambrian age. The largest deposits are found in Sri Lanka and India. Several authors have proposed a linkage between these deposits (along with syngenetic deposits in the same areas of India and in Madagascar) as they occur in adjacent crustal fragments within East Gondwana that were affected by a Late Pan-African granulite-facies metamorphic event (e.g., Radhika and Santosh 1995; Dissanayake and Chandrajith 1999). The important syngenetic graphite deposits from the Jiamusi massif (China) would be also included in this realm (Wilde et al. 1999). The vein deposit at Dillon (Montana, USA), hosted in Precambrian upper-amphibolite to granulite facies quartzofeldspathic ortho- and paragneisses, also shares many features with the previously mentioned granulite-hosted deposits (Duke et al. 1990). This deposit was mined in the past but it is currently uneconomic.

Most of the graphite veins from Sri Lanka are scattered throughout the medium- to high-P/high-T granulite facies terranes of the Highland Complex, where the largest deposits are located (Fig. 2). Some authors consider the western Highland Complex to be part of the Wanni Complex, and thus locate graphite vein deposits within the Wanni Complex (e.g., BinuLal et al. 2003). The Highland Complex consists of aluminous migmatitic gneisses, intercalated with mafic granulites, calcsilicate gneisses, and orthopyroxene-bearing granitic rocks (charnockites). Peak metamorphic conditions were attained at 550-610 Ma (Kröner and Williams 1993) and are estimated to be about $1,100{ }^{\circ} \mathrm{C}$ and up to $12 \mathrm{kbar}$ in the central area of the Complex (Sajeev and Osanai 2004). Early research on graphite veins suggested that they were related to anticlinal structures that were developed coevally with the peak of the granulitefacies metamorphism (Silva 1974; Katz 1987). However, more recent studies have revealed that graphite veins are located close to the axial traces of both antiformal and synformal structures along extensional fractures which postdated the granulite-facies metamorphic event (Kehelpannala 1999; Kehelpannala and Francis 2001). Host rocks to the deposits vary depending on the mineralized area (Dinalankara and Dissanayake 1988), but pelitic and charnockitic gneisses are the dominant host-rock lithologies which, in turn, contain variable amounts of disseminated graphite flakes. The ore bodies are irregular to tabular, usually branched and locally forming groups of several parallel members (Katz 1987; Kehelpannala 1999). En-echelon arrays of graphite veins are common, suggesting extensional fractures (Kehelpannala 1999). The graphite veins are mostly steeply dipping (Fig. 3), and in places, they are spatially associated with pegmatite bodies and quartz veins. Thickness of the graphite veins is quite variable, ranging from a few millimeters to $1 \mathrm{~m}$. Their length ranges from a few meters to over $75 \mathrm{~m}$. Hydrothermal alteration has been recognized around the graphite veins (Fig. 4a), characterized by the occurrence of hydrous and/or chlorine-rich minerals (biotite, chlorite, hornblende, and scapolite) and by an increase in the K-feldspar content (Silva 1987; Kehelpannala 1999; Kehelpannala and Francis 2001).

Graphite is the only mineral in most of the veins, but locally pyrite, chalcopyrite, calcite, quartz, apatite, and biotite may be associated with it. Two main textural types of graphite can be recognized within the veins (Katz 1987; Touzain et al. 2010). 


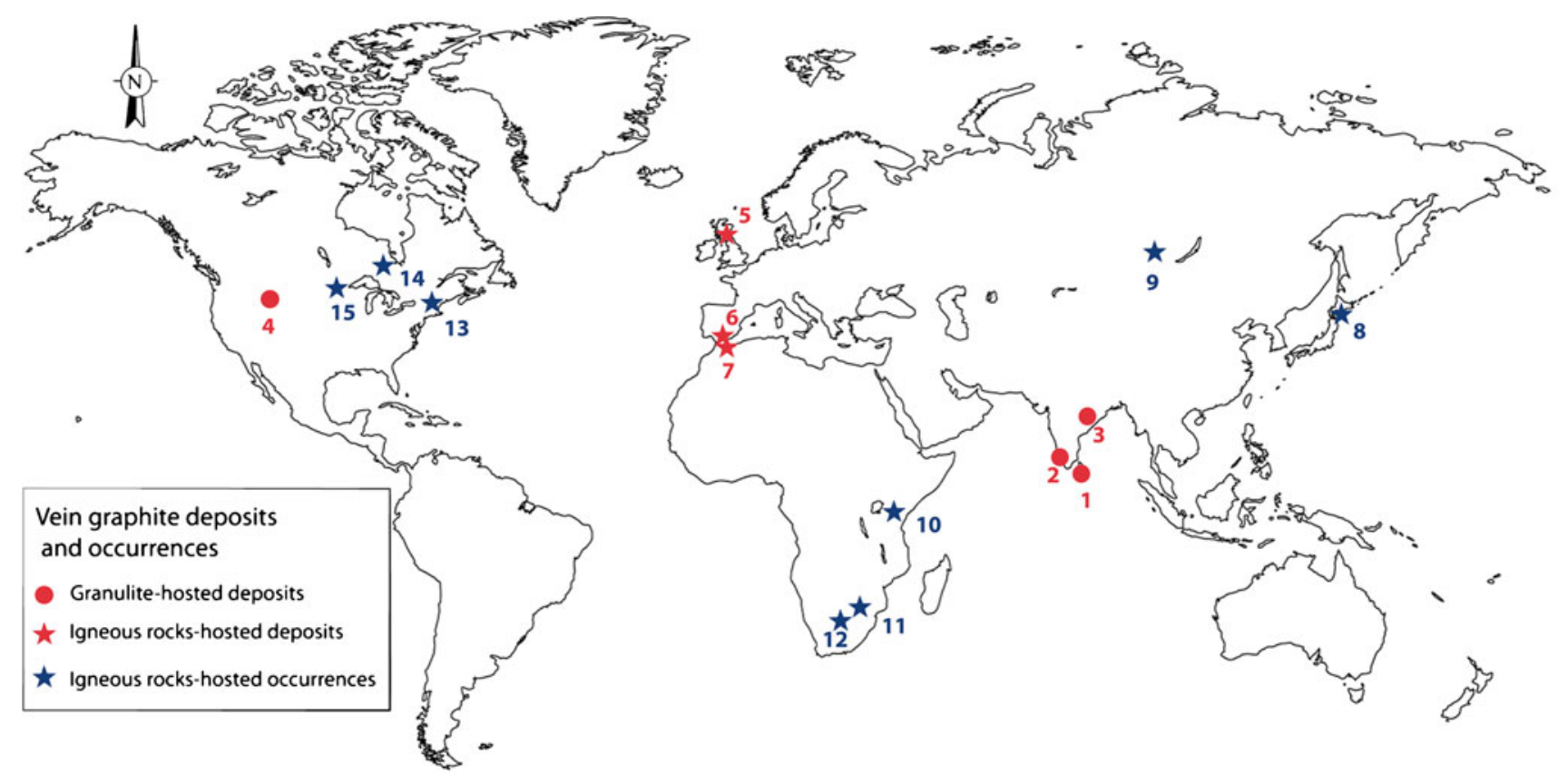

Fig. 1 World distribution of vein graphite deposits and occurrences. Symbols in red correspond to the vein deposits described in this paper. 1 Sri Lanka (see Fig. 2 for details), 2 Kerala (India), 3 Orissa (India), 4 Dillon (USA), 5 Borrowdale (UK), 6 Serranía de Ronda (Spain), 7 Beni Bousera (Morocco), 8 Oshirabetsu (Japan; Tsuchiya et al. 1991), 9 Botogol massif (Siberia, Russia; Chukhrov et al. 1984), 10 Merelani

The first textural type corresponds to relatively coarse flakes or needles, which are oriented perpendicular to the vein walls (Fig. 4b). The second type is fine grained rosettes or spherulitic graphite aggregates (Fig. 4c). Both types may occur within a single vein (Silva 1987; Touzain et al. 2010). This may also result in a zoning pattern across the vein indicating successive opening of the fractures.

In India, most of the syngenetic and epigenetic graphite deposits extend from Orissa to Kerala (Fig. 1; Krishna Rao and Malleswara Rao 1965; Sinha 1982; Soman et al. 1986; Radhika et al. 1995). They occur associated with Precambrian high-grade, granulite facies rocks with mineral assemblages corresponding to high temperature $\left(650-850^{\circ} \mathrm{C}\right)$, high pressure conditions (8-10 kbar; Acharya and Dash 1984), and a low $\mathrm{H}_{2} \mathrm{O}$ activity. Peak metamorphic temperatures might have been even higher, considering the increasing reports of UHT metamorphism in eastern India (e.g., Tadokoro et al. 2007). Studies on vein graphite deposits in India are scarce and were carried out some time ago (e.g., Krishna Rao and Malleswara Rao 1965; Acharya and Dash 1984; Soman et al. 1986). However, more recent studies have dealt with graphite occurrences in these granulite rocks providing further evidence on the origin of the deposits (e.g., Santosh and Wada 1993a, b; Radhika and Santosh 1996; Satish-Kumar 2005; Baiju et al. 2009; Satish-Kumar et al. 2011). Vein graphite deposits in India, like those in Sri Lanka, are not restricted to any specific lithology but they are hosted by a wide diversity of metamorphosed
(Tanzania; Jaszczak and Trinchillo 2013, and references therein), 11 Bushveld Complex (South Africa), 12 Kimberley (South Africa), 13 New Hampshire (USA), 14 Albany graphite prospect (Canada; P. Wood, pers. com.; www.zenyatta.ca), 15 Duluth Complex (USA). For additional data on occurrences 11-13 and 15, see Luque et al. (1998) and references therein

sedimentary and igneous rocks (Acharya and Dash 1984; Acharya and Rao 1998). Therefore, there is not lithological control on vein graphite mineralization, although Acharya and Rao (1998) reported affinity of graphite veins to khondalitecalc-silicate granulite assemblages in some deposits in the Eastern Ghat Complex in Orissa. However, it is interesting to mention the common association of graphite veins with pegmatites (Acharya and Dash 1984; Soman et al. 1986). Graphite ore bodies occur as veins or lenses along the contacts of pegmatites. Association with pegmatites and textural occurrence (also reported by Satish-Kumar et al. 2011) show that graphite precipitation was synchronous with melt crystallization, that is, occurred during cooling and post-dated the metamorphic peak. The graphite veins show branching patterns within their host rocks (Acharya and Dash 1984). Thickness of up to $70 \mathrm{~cm}$ for some veins in south Kerala has been reported (Soman et al. 1986). The carbon content of the mineralized bodies may reach up to $95 \%$. Quartz, pyrite and pyrrhotite are the most common gangue minerals in the veins. Both flaky and acicular graphite (often as radial aggregates) occur within the veins. Acicular graphite is usually oriented perpendicular to the vein walls.

At Dillon (Montana, USA; Fig. 1) country rocks to the graphite vein deposit are Archean (2.75 Ga) upper amphibolite to granulite facies metamorphic rocks comprising garnetiferous granite gneiss, schists, marbles, and quartzites, as well as small pegmatite bodies. Similar to the deposits in Sri Lanka and India, host rocks to the graphite veins contain 


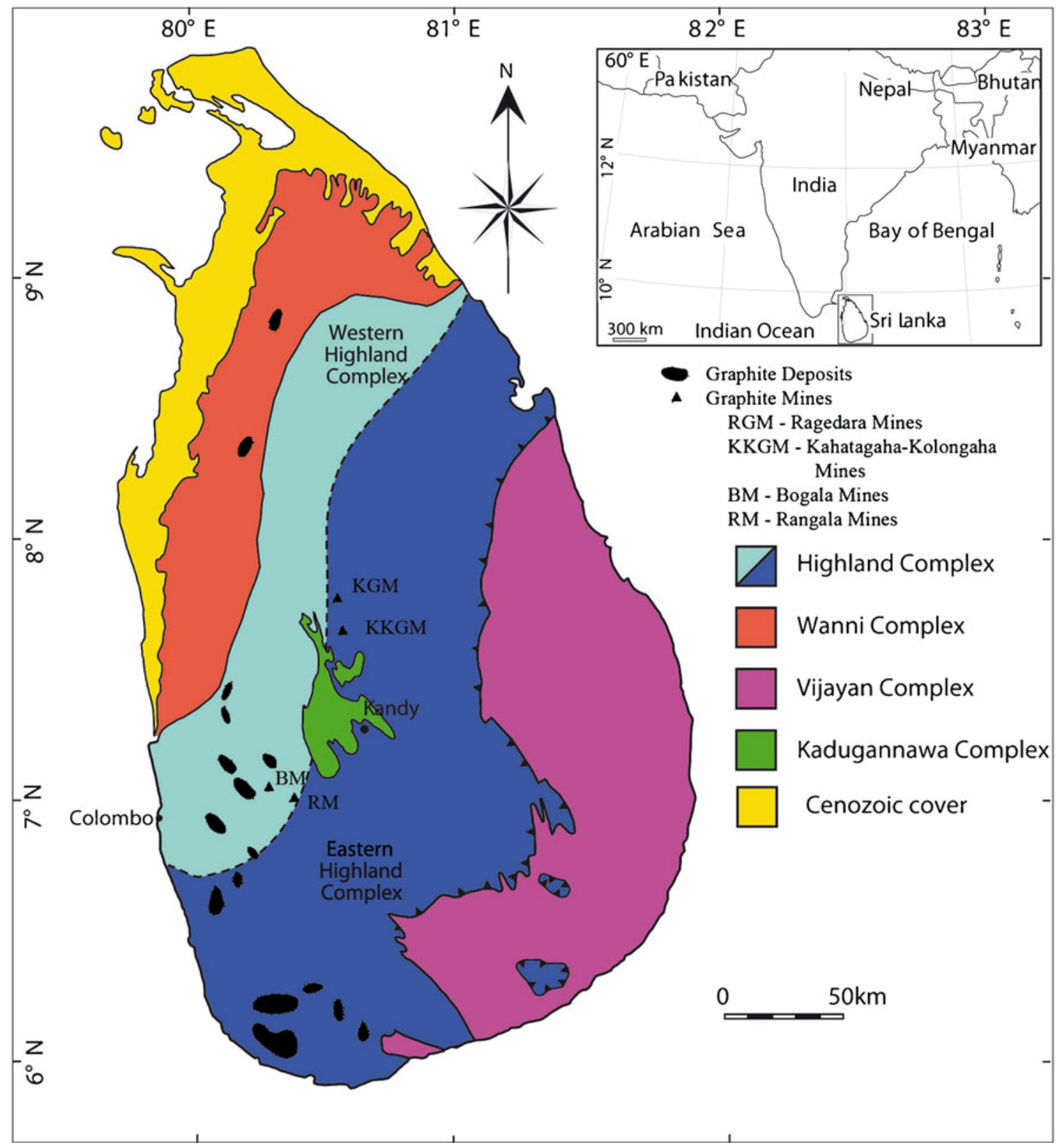

Fig. 2 Geological map of Sri Lanka showing the location of graphite deposits within granulite-facies rocks. Modified from Binu-Lal et al. (2003) and Sajeev and Osanai (2004)

disseminated flaky graphite. Peak metamorphic conditions are estimated to be in the range $750-800{ }^{\circ} \mathrm{C}$ and $5.4-7.7 \mathrm{kbar}$ (Duke et al. 1990). Also in this deposit there is no lithological control on vein graphite occurrence, but the richest graphite ore in the deposit occurs as fracture fillings in gneisses and pegmatites located around the northwesterly plunging nose of an isoclinal synform (Cameron and Weis 1960). These field relationships indicate that graphite precipitated after significant cooling with respect to peak temperature, once the rocks had a brittle behaviour. Interestingly, graphite does not occur in marble. Graphite occurs as thin films, veinlets and veins up to $0.6 \mathrm{~m}$ thick and $15 \mathrm{~m}$ long. Locally, intersecting veins produce stockwork-like structures. Contacts between graphite veins and host rocks are sharp with no alteration of the rocks around the veins (Ford 1954; Duke et al. 1990). Graphite is the only important mineral in the veins, although some quartz is locally associated with it. Platy graphite up to $2.5 \mathrm{~cm}$ in length occurs in the veins, but comb textures are also found in some places (Cameron and Weis 1960).

Igneous-hosted deposits

Vein graphite occurrences have been described in a wide variety of igneous rocks (Luque et al. 1998). Among these 


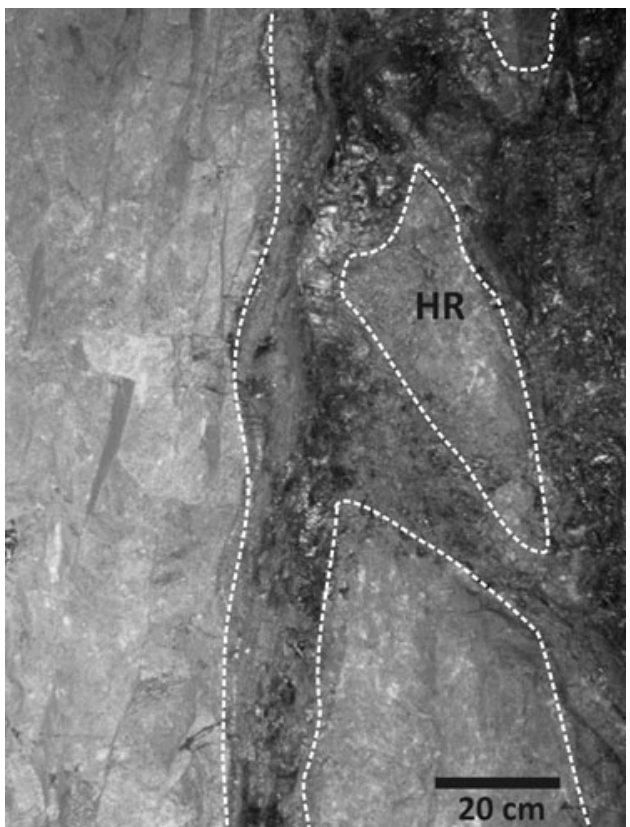

Fig. 3 Graphite veins in granulite rock. Note branching of the veins and the host-rock fragments between veins. The dashed line marks the contact with the host rock. Kahatagaha mine, Sri Lanka

occurrences there are some well-documented deposits with past economic interest, in particular that at Borrowdale (Cumbria, UK) where graphite was discovered, and several mines in the Serranía de Ronda (southern Spain) and Beni Bousera (Morocco; Fig. 1). Other examples of the old mines of vein graphite in igneous rocks include those of the Botogol massif (Russia) hosted by nepheline syenites. There are no reports of graphite veins in igneous rocks currently being mined.

The Borrowdale graphite deposit occupies about a 400-m length of a conjugate set of normal faults and it is hosted by andesite lavas and sills belonging to the upper Ordovician Borrowdale Volcanic Group, and by a probably contemporaneous hypabyssal dioritic intrusion. The volcanic rocks are underlain by anchizonal to epizonal metapelites of the upper Cambrian to middle Ordovician Skiddaw Group. Graphite in the Borrowdale deposit occurs as: (a) subspherical to ellipsoidal nodular masses (typically $1-2 \mathrm{~cm}$ in diameter, though nodules up to $1 \mathrm{~m}$ in diameter have been reported; Fig. 5) in pipe-like bodies along fault intersections (up to $1 \times 3 \mathrm{~m}$ in cross-section and from a few metres to over $100 \mathrm{~m}$ in length), (b) fault veins in the volcanic rocks, usually associated with chlorite, and (c) as disseminate replacement (disseminations) within the volcanic host rocks (Ortega et al. 2010). The main mineralized body has an important structural control, with graphite occurring within subvertical pipes developed at the intersection of normal conjugate fractures which are also mineralized. The yellow-brown matrix within the mineralized pipe-like bodies comprises intensely altered wall-rock and brecciated quartz. Also, both the andesite and dioritic host
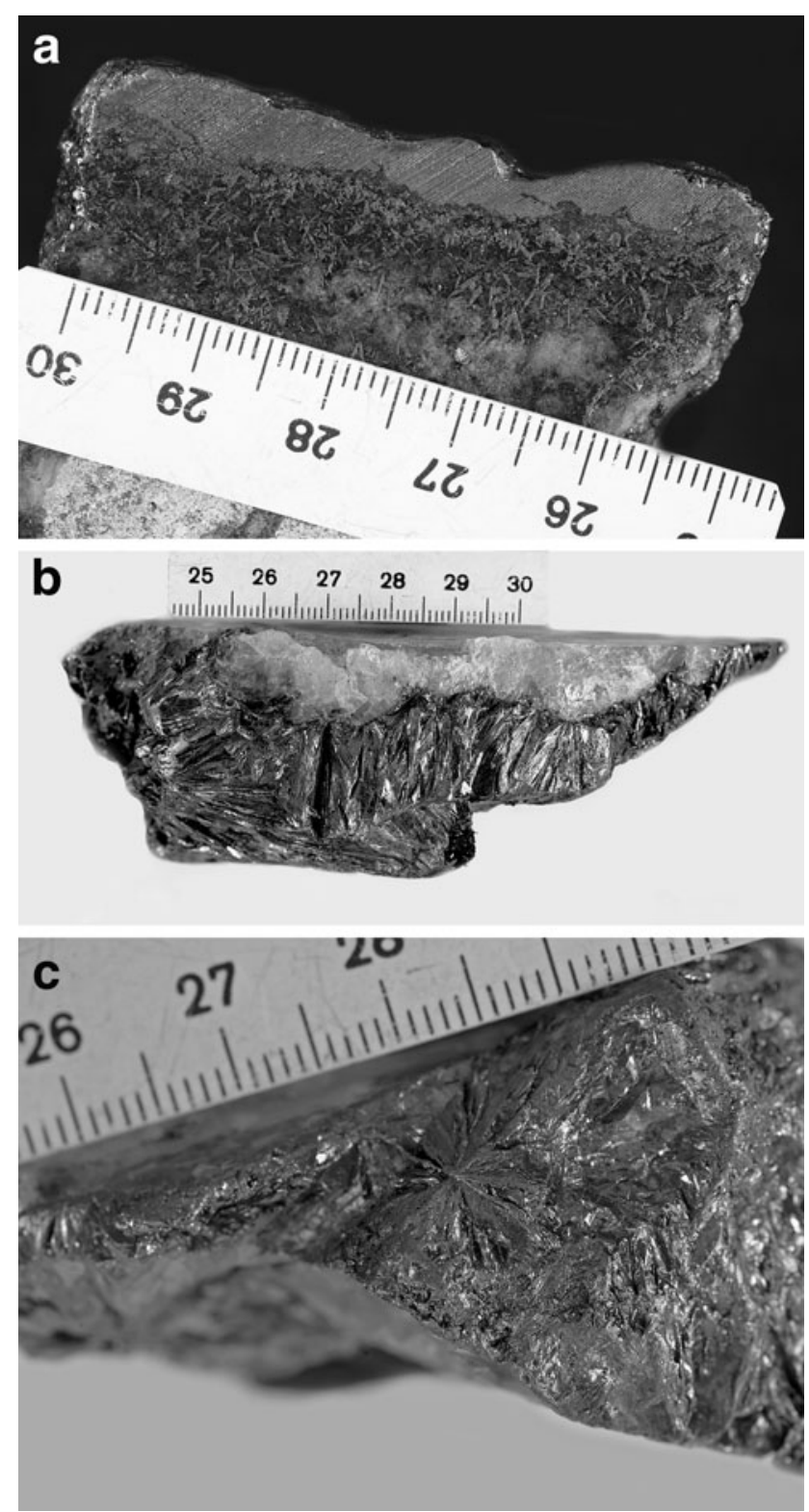

Fig. 4 a Sample of a small graphite vein within garnet-bearing charnockitic gneiss from Bogala mine, Sri Lanka. Note the greenish alteration halo around the vein in which disseminated small graphite flakes occur. Scale in centimeters. b Sample of coarsely crystalline flaky graphite on quartz. Note the graphite crystals perpendicular to the quartz selvage of the vein. Bogala mine, Sri Lanka. Scale in centimeters. c Detail of a rosette-like aggregate of graphite crystals. Bogala mine, Sri Lanka. Scale in centimeters

rocks veins have been intensely hydrothermally altered to a propylitic assemblage containing quartz, chlorite, epidote, sericite, and albite, along with some disseminated small aggregates of graphite and late calcite veinlets (Ortega et al. 2010; Luque et al. 2012a).

The ultramafic massifs of the Serranía de Ronda (southern Spain) and Beni Bousera (Morocco) are located in the BeticRifean orogenic belt, which is the westernmost part of the Mediterranean Alpine belt. The massifs comprise lherzolites 


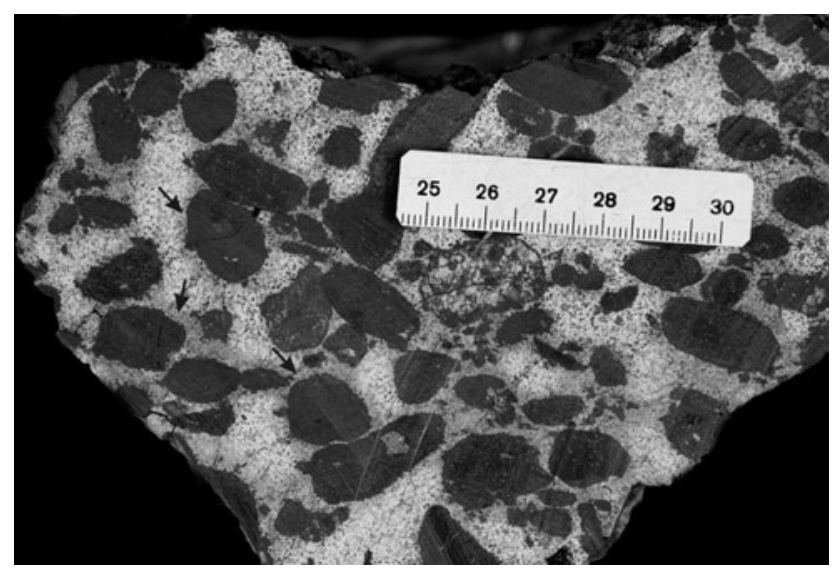

Fig. 5 Sample from the breccia-pipe ore body of the Borrowdale deposit showing the typical nodular texture of graphite. Note the alteration haloes (marked by arrows) around graphite nodules. Scale in centimeters

and harzburgites with minor dunites, different types of pyroxenite layers, and leucocratic dikes. Graphite ore bodies occur as veins, stockworks and irregular masses with very variable size (from some centimeters to few meters in thickness). Lateral extension is up to some tens of meters. These ores are associated with late fault zones within spinel and garnetspinel peridotites (Crespo et al. 2006a). The primary mineral assemblage of the veins mainly consists of graphite, $\mathrm{Fe}-\mathrm{Ni}-\mathrm{Cu}$ sulfides (pyrrhotite, pentlandite, chalcopyrite, and cubanite), and chromite (Fig. 6; Luque et al. 1992; Crespo et al. 2006a). Graphite content varies from 10 to 60 vol \%. In sulfide-poor deposits weathering has transformed the original sulfides into earthy masses of $\mathrm{Fe}$ oxi-hydroxides containing irregular to rounded graphite concentrations.

\section{Mineralogy and geochemistry}

Graphite veins (except for those in the Serranía de Ronda) are almost monomineralic. Quartz is often found in granulitehosted veins and is also associated with graphite in the Borrowdale deposit. The study of fluid inclusions in quartz within graphite veins has provided important data about the genesis of the deposits as it will be discussed later.

Reflected light optical microscopy reveals that the most common morphology of graphite in vein deposits is flaky. This is the only morphology described for graphite in granulite-hosted deposits. However, graphite veins and nodules from the Borrowdale deposit exhibit the greatest variety of crystalline graphite morphologies recognized to date from a single deposit (Barrenechea et al. 2009). Graphite in the nodules and patches from the pipes mainly occur as (a) flakes (the most abundant morphology in the deposit, $>90 \mathrm{vol} \%$ ), (b) cryptocrystalline aggregates (mostly as colloform masses usually surrounded by flaky graphite), and (c) spherulites (5-40 $\mu \mathrm{m}$ in diameter, within laminar graphite). Composite

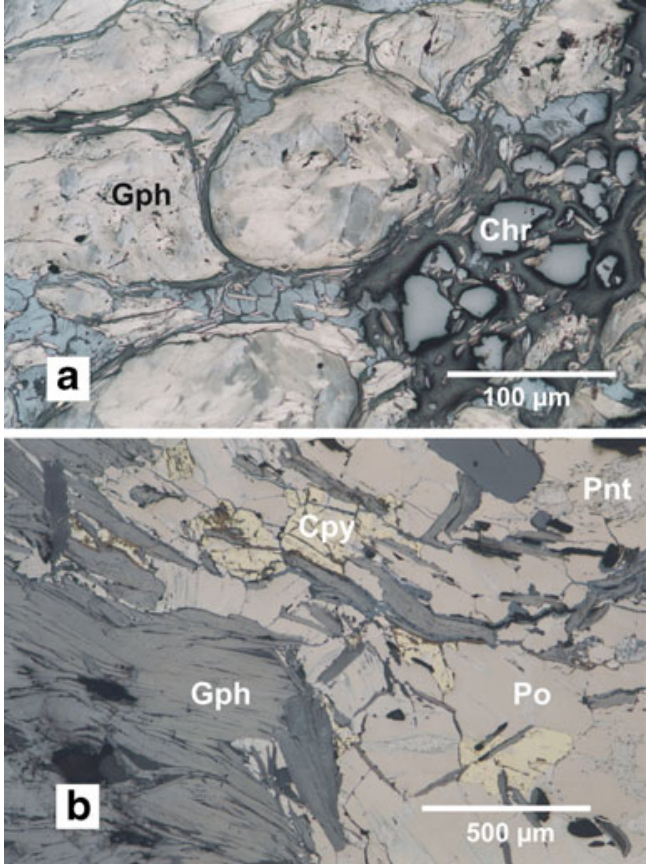

Fig. 6 a Reflected light photomicrograph (plane-polarized light) of rounded aggregates of graphite flakes from Tafart West deposit, Beni Bousera, Morocco. b Reflected light photomicrograph (plane-polarized light) showing the primary mineral assemblage of the peridotite-hosted graphite veins (Mina del Río deposit, Beni Bousera, Morocco). Gph graphite, Po pyrrhotite, Pnt pentlandite, Cpy chalcopyrite, Chr chromite

nodules formed by cryptocrystalline graphite surrounded by flaky graphite have been found. Both spherulitic and flaky graphite has also been found in late chlorite-graphite veins at Borrowdale. Crespo et al. (2006a) described cubic-shaped graphite morphologies from the ultramafic-hosted graphite veins in the Serranía de Ronda. This habit corresponds to graphite pseudomorphs after diamond. In addition, graphite in these deposits within ultramafic rocks also occurs as rounded aggregates of flaky crystals (Fig. 6a).

Structural data on graphite from vein occurrences demonstrate that graphite is highly crystalline, that is, it is characterized by large crystallite sizes both along the stacking direction (c axis) and the basal plane (Luque et al. 1998). This was related to the high temperature required for graphite veins to form (Luque and Rodas 1999; Pasteris 1999). However, recent studies on the vein deposit at Borrowdale have shown that graphite is highly crystalline even if it was formed at moderate temperatures $\left(400-500{ }^{\circ} \mathrm{C}\right.$; Luque et al. 2009).

$\mathrm{X}$-ray diffraction data of vein graphite from Sri Lanka yields interlayer spacings between successive carbon layers $\left(\mathrm{d}_{002}\right)$ very close to that in the ideal hexagonal graphite structure. Katz (1987) reported minor differences in the interlayer spacing of texturally different graphites from the veins of the Bogala mine, being spherulitic graphite $(c=6.70 \AA)$ slightly higher crystalline than flake-acicular graphite $(c=6.72 \AA)$. Matsuura et al. (2007) and Touzain et al. (2010) also found 
minor differences in the interlayer spacing of graphite depending on the crystal morphology. From these values, the crystallite sizes along the stacking direction of the carbon layers within the structure are in the range from 780 to $450 \AA$ (Crespo et al. 2003, 2006b; Matsuura et al. 2007; Touzain et al. 2010). Similar values are reported for vein graphite from South Kerala (Soman et al. 1986).

The intensity and area ratios between the order (G-peak at $\approx 1,580 \mathrm{~cm}^{-1}$ ) and disorder peaks (D1-peak at $\approx 1,350 \mathrm{~cm}^{-1}$ and D2-peak at 1,620 $\mathrm{cm}^{-1}$ ) in the first-order Raman spectrum can be used to estimate the crystallite size along the $a-b$ plane of the graphite structure (e.g., Wopenka and Pasteris 1993). Raman spectra of graphite concentrates (after crushing and sieving) from Bogala mine show a high degree of order in the arrangement of carbon atoms within the basal plane, with crystallite size along this plane exceeding $1,000 \AA$. The spectra are, therefore, compatible with the fully ordered graphite structure (Crespo et al. 2003, 2006b; Touzain et al. 2010).

The temperature of combustion of vein graphite from Sri Lanka and India is also typical of highly crystalline graphite, with strong exothermic peaks in the differential analysis (DTA) curves at $T>800{ }^{\circ} \mathrm{C}$ (Fig. 7; Soman et al. 1986; Crespo et al. 2003, 2006b; Matsuura et al. 2007; Touzain et al. 2010).

Similar structural (Fig. 8) and thermal data have been reported for igneous-hosted graphite veins both in the Serranía de Ronda, Beni Bousera, and Borrowdale deposits (Luque et al. 1992; Crespo et al. 2006a; Luque et al. 2009; Barrenechea et al. 2009; Ortega et al. 2010). The different graphite morphologies found in the Borrowdale deposit are structurally highly crystalline (Barrenechea et al. 2009). At this point, it is important to note that the crystallinity of vein graphite is irrespective of its specific temperature of formation. This implies that the Raman geothermometer of graphite fails to estimate the crystallization temperature. Thus, the

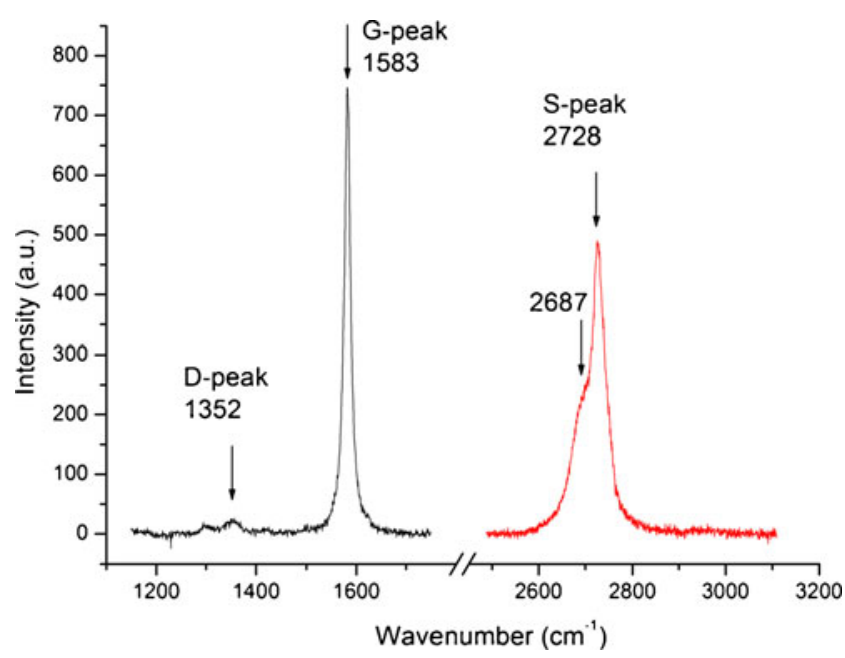

Fig. 8 First- and second-order Raman spectra of graphite from El Águila deposit, Serranía de Ronda. Note the low intensity of the D-peak at $\approx 1,350 \mathrm{~cm}^{-1}$ and the low intensity and area ratios of the D- to G-peak in the first-order spectrum. These features, as well as the shoulder at $\approx 2,686 \mathrm{~cm}^{-1}$ on the S-peak in the second-order spectrum (in red), are indicative of a high crystallinity along the basal plane in the graphite structure. The spectrum was obtained using the $514.5 \mathrm{~nm}$ wavelength of an $\mathrm{Ar}^{+}$laser

application of the graphite Raman geothermometer, which is considered by many authors adequate to address temperatures of formation in graphite formed through metamorphism of carbonaceous matter (e.g., Beyssac et al. 2002), is not suitable for vein graphite. As temperature is a key parameter for the genetic interpretation, it is important to be able to constrain the temperature of graphite deposition in veins by other methods, such as fluid inclusion microthermometry (Ortega et al. 2010).

Stable carbon isotope geochemistry of graphite from vein deposits shows interesting features. Graphite from granulitehosted deposits has relatively ${ }^{13} \mathrm{C}$-enriched signatures compared with graphite in igneous-hosted deposits which shows $\delta^{13} \mathrm{C}$ values significantly lower.
Fig. 7 Differential thermal analysis (DTA) and thermogravimetric (TG) curves of graphite from Bogala mine, Sri Lanka. Analytical conditions: continuous air supply $(50 \mathrm{~mL} / \mathrm{min})$ and heating rate of $10^{\circ} \mathrm{C} / \mathrm{min}$

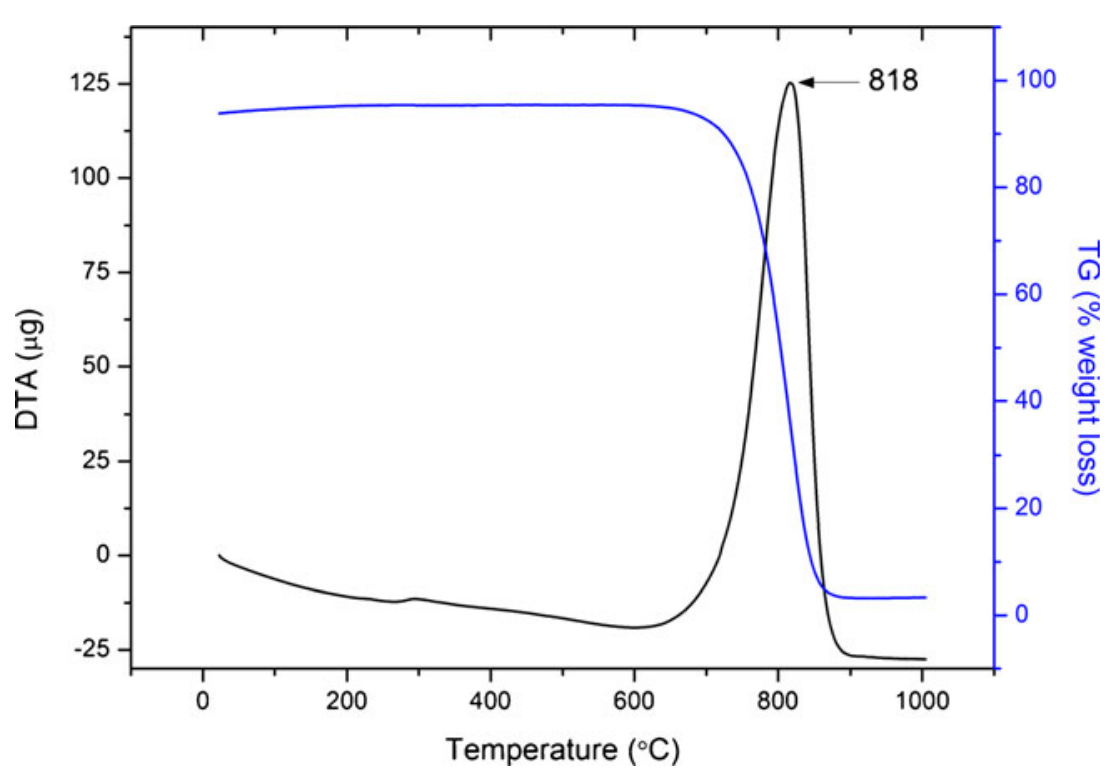


A large number of papers have dealt with the isotopic characterization of graphite from vein deposits in Sri Lanka (e.g., Dobner et al. 1978; Weis et al. 1981; Binu-Lal et al. 2003; Touzain et al. 2010). The reported $\delta^{13} \mathrm{C}$ values range from $-6 \%$ to $-10 \%$. Touzain et al. (2010) have observed isotopic variation across the veins, with slightly heavier $\delta^{13} \mathrm{C}$ values in graphite from the contact with the host rocks $\left(\delta^{13} \mathrm{C}=-9.4 \%\right)$ and isotopically lighter values at the center of the veins $\left(\delta^{13} \mathrm{C}=-10.3 \%\right.$ ). It is important to note that vein graphite is considerably heavier than dispersed graphite within the granulite host-rocks $\left(\delta^{13} \mathrm{C}=-12 \%\right.$ to $-17.9 \%$; HahnWeinheimer and Hirner 1981; Hoernes et al. 1994).

Graphite from vein deposits in India also shows isotopically heavy signatures $\left(\delta^{13} \mathrm{C}\right.$ higher than $-12 \%$ ) compared to disseminated graphite within their host rocks $\left(\delta^{13} \mathrm{C}\right.$ up to -34 \%o; Soman et al. 1986; Acharya and Rao 1998). In addition, Duke et al. (1990) also reported high $\delta^{13} \mathrm{C}$ values in vein graphite $\left(\delta^{13} \mathrm{C}=-5.8 \%\right.$ to $-8.2 \%$ ) and lighter signatures $\left(\delta^{13} \mathrm{C}=-30 \%\right)$ in flake graphite from the enclosing schists in the Dillon deposit.

Detailed isotopic studies at the microscale in graphite from vein occurrences in granulite terranes demonstrate isotopic variations within single graphite crystals (Binu-Lal et al. 2003; Luque et al. 2012b, and references therein).

Carbon isotope geochemistry of graphite from vein deposits hosted by igneous rocks shows a completely different systematics. At Borrowdale, light isotopic signatures have been reported for all graphite morphologies, ranging from $-33.7 \%$ to $-30.3 \%$ within the nodules of the main pipe-like ore body, the lower values corresponding to cryptocrystalline graphite and the higher ones to flaky graphite (Barrenechea et al. 2009; Ortega et al. 2010). Late chlorite-graphite veins have $\delta^{13} \mathrm{C}$ values ranging from $-34.5 \%$ to $-30.1 \%$, where spherulitic graphite heavier than flaky graphite. Bulk carbon isotope analyses and isotopic studies at the microscale of graphite from the Serranía de Ronda and Beni Bousera deposits yielded ${ }^{13} \mathrm{C}$ depleted values (average $\delta^{13} \mathrm{C} \approx-16 \%$; Luque et al. 1992; Crespo et al. 2006a). Locally, in nodule-like graphite aggregates large isotopic zoning has been found $\left(\delta^{13} \mathrm{C}\right.$ ranges from $-3.3 \%$ to $-15.2 \%$ ), being the core of the nodule isotopically heavier than the rim. The heaviest values inside the aggregates correspond to cubic forms which have been interpreted as graphitized diamonds (Crespo et al. 2006a).

\section{Processes of vein graphite formation}

Many theories have been proposed to explain the genesis of vein graphite deposits in granulite rocks. Current theories support the formation of the veins by graphite precipitation from carbon-rich fluids along fracture systems. Such a mechanism also operated in the formation of graphite veins at Borrowdale, although the composition of fluids was quite different. The graphite-sulfide veins at Serranía de Ronda and Beni Bousera appear to be a singular type of occurrence where graphite was deposited from a carbon-rich melt.

The genetic hypothesis for vein graphite must address at least three points: (a) the origin of carbon, (b) the mechanisms of mobilization, and (c) the mechanisms of deposition. Many contrasting theories have evolved from the earlier works on vein graphite. Below, the different theories suggested for the origin of graphite veins in granulites will be examined and then the actual processes involved in their formation will be discussed on the basis of the geological, mineralogical and geochemical evidence. Because the origin of vein graphite deposits in igneous rocks involves processes not achieved in granulite rocks it will be discussed in an independent section.

\section{Granulite-hosted deposits}

\section{Origin of carbon}

Considerable debate has been focused on the origin of carbon in graphite vein deposits in granulites. Until the routine application of stable carbon isotope ratios to decipher the origin of carbon in graphite, arguments favouring the biogenic or abiogenic derivation of carbon were based on field data or on experimental chemistry and thermodynamic calculations in carbon systems (Erdosh 1970, 1972; Salotti et al. 1971, 1972). Even after the isotopic data were available, the origin of carbon in such deposits has been a matter of some debate (e.g., Dissanayake 1994).

Because the main sources of carbon (organic matter, carbonates, and mantle) are characterized by different isotopic ranges, the ratios of stable carbon isotopes are useful for interpreting the ultimate origin of carbon in graphite. Thus, the average $\delta^{13} \mathrm{C}$ value for organic matter is about $-25 \%$; marine carbonates of Cambrian to Tertiary age, on the other hand, have higher $\delta^{13} \mathrm{C}$ $(-2 \%$ to $0 \%$ ); and, finally, the isotopic compositions of diamonds and mid-oceanic ridge basalts (MORB) indicate that mantle-derived carbon is significantly heavier $\left(\delta^{13} \mathrm{C} \approx-7 \%\right.$ o) than biogenic carbon. However, in syngenetic graphite occurrences this straightforward relation of the carbon isotopic signature in terms of the carbon source is usually modified by the fractionation effects depending upon the temperature and the presence of other mineral phases (carbonates). The recognition of the origin of carbon in fluid-deposited graphite is even more complicated because of the possibility of mixing different carbon reservoirs before or while graphite precipitated from the fluid and by the fractionation of carbon between the species in the fluid and graphite during the evolution of the fluid (see Luque et al. 2012b for a comprehensive discussion).

Taking in mind these factors, biogenically derived graphite having experienced high temperature metamorphism and isotopic exchange with a carbonate phase would acquire an isotopic signature significantly much heavier than that of its 
original source. On the other hand, graphite of biogenic origin which has been overgrown by graphite precipitated from a $\mathrm{CO}_{2}$-rich fluid released from decarbonation reactions or from mantle-derived $\mathrm{CO}_{2}$ would also have a bulk isotopic ratio heavier than the typically low $\delta^{13} \mathrm{C}$ value of biogenic graphite. Mechanical mixtures of graphite derived from different carbon sources would also result in intermediate bulk isotopic signatures (e.g., Farquhar and Chacko 1991; Baiju et al. 2009). Thus, even considering the data of stable carbon isotope ratios of graphite, the recognition of the biogenic or abiogenic origin can be difficult to prove in some instances as pointed out by Dissanayake $(1981,1986)$ for the vein deposits of Sri Lanka. This conclusion introduces a degree of uncertainty in some genetic models based solely on $\mathrm{C}$ isotopic data, which appears to be particularly important for felsic systems, as there is not quantitative information on the fractionation of $\mathrm{C}$ isotopes between melt, graphite and $\mathrm{C}-\mathrm{O}-\mathrm{H}$ fluids (Satish-Kumar et al. 2011).

It should be noted that in most of the granulite-hosted veins (deposits and minor occurrences) carbon isotope ratios of disseminated graphite in the host rocks and those of graphite veins are clearly different and this can be hardly explained by fractionation and/or mechanical mixing, thus indicating different sources. Usually, as previously mentioned, disseminated graphite within the granulite host rock has low isotopic ratios that suggests a biogenic origin (e.g., Soman et al. 1986; Duke et al. 1990; Hoernes et al. 1994; Radhika and Santosh 1996; Acharya and Rao 1998). The large isotopic difference between disseminated and vein graphite can be interpreted as an evidence that there is not a common origin for both types of graphite. If carbon in vein graphite is not biogenic, two alternative sources must be considered to explain its heavy isotopic signature (Fig. 9): (a) $\mathrm{CO}_{2}$ of mantle origin and (b) $\mathrm{CO}_{2}$ derived from decarbonation reactions of carbonatebearing lithologies. The discrimination between these sources based solely on the carbon isotope ratios is difficult. However, many studies on granulites favour the derivation of carbon from sublithospheric magmas (e.g., Vry et al. 1988; Farquhar and Chacko 1991; Santosh and Wada 1993a; Wada and Santosh 1995; Radhika and Santosh 1996; Kehelpannala 1999; Santosh and Omori 2008a, 2008b; Touret and Huizenga 2012). This, however, does not preclude the local role of $\mathrm{CO}_{2}$ released from decarbonation reactions in the genesis of some vein graphite occurrences in granulite terranes where marbles and calc-silicate rocks occur (e.g., Hapuarachchi 1977; Duke et al. 1990; Santosh and Wada 1993b; Santosh et al. 2003; Crespo et al. 2004).

\section{Mechanisms of carbon mobilization}

Carbon involved in the formation of vein graphite can be transported in two different states. The first corresponds to the mobilization in the solid state; the second is dissolution in

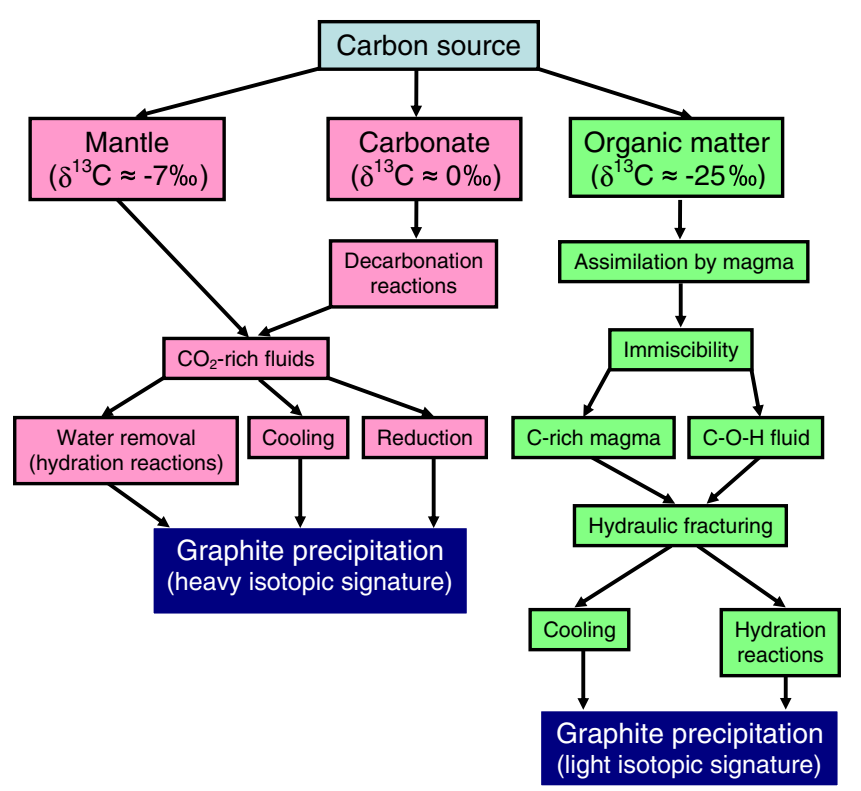

Fig. 9 Diagram summarizing the mechanisms involved in vein-graphite mineralization in granulite-facies rocks (left side, in pink) and in igneous rocks (right side, in green)

aqueous fluids, or more rarely in melts, of various carbon species (mainly $\mathrm{CO}_{2}$ and/or $\mathrm{CH}_{4}$, under most geological conditions).

Mobilization in the solid state was suggested by Erdosh (1970) to explain the origin of vein deposits in Sri Lanka. He argued that under granulite-facies temperature and pressure conditions the migration and accumulation of graphite dispersed in the host metasediments towards low pressure zones (fractures) would be a feasible mechanism. Such a mechanism was also invoked by Acharya and Dash (1984) and Acharya and Rao (1998) for the formation of granulite-hosted vein graphite deposits in India. The mobilization of graphite in the solid state, however, has been refuted by other authors (e.g., Salotti et al. 1972) on the basis of textural features and purity of the graphite veins. These authors suggested that the presence of admixed country rock fragments could be hardly avoided in the process of physical mobilization. Other arguments against graphite mobilization include the difference between structural and isotopic data of graphite in the source granulite rocks and graphite in the veins. The only proven example, to our knowledge, of solid state graphite mobilization resulting in graphite veins, is a graphite occurrence in the Spanish Central System described by Crespo et al. (2005). Here, the vein graphite shows no isotopic difference with the graphite in the host-rock. Further, the crystallinity of vein graphite shows a decrease compared to the host-rock graphite, which is to be expected if graphite moves along grain boundaries. The granulite-hosted vein deposits in Sri Lanka, India, and Montana are lacking these characteristics, which excludes solid state remobilization as a potential process. The graphite veins in these granulites must be, therefore, the result of graphite precipitation from a fluid phase. 
The transport of carbon as gaseous molecular species dissolved in a fluid was already suggested in the earliest papers on the vein graphite deposits of Sri Lanka (e.g., Bastin 1912). Tectonically weakened zones (faults, shear zones) favour fluid infiltration as they provide migration channels for C-O-H fluids. Thus, the formation of graphite veins along the fracture system is related to the movement of fluids along these pathways. In addition, the increase of fluid pressure can promote the development of hydraulic fracturing, which also would contribute to the formation of graphite veins (Fig. 9; Luque et al. 1998).

The involvement of $\mathrm{CO}_{2}$ fluids in granulite facies metamorphism is well documented, as recently summarized in the papers by Touret and Huizenga $(2011,2012)$ and Huizenga and Touret (2012). One important observation is the presence of $\mathrm{CO}_{2}$ fluid inclusions in minerals of granulitic assemblages (e.g., Touret 1971; Jackson et al. 1988; Vry et al. 1988; SatishKumar and Santosh 1998). The presence of such $\mathrm{CO}_{2}$-rich fluids in the rock system has been related to internally-derived fluids (Hansen et al. 1987; Cesare et al. 2005) or externallyderived fluids (Newton et al. 1980; Farquhar and Chacko 1991; Wada and Santosh 1995). Sources of $\mathrm{CO}_{2}$ may include magmatic, mantle-derived fluids, metamorphic decarbonation reactions, and devolatilization reactions of organic matter (e.g., Santosh and Omori 2008a). However, current interpretations favour the derivation of $\mathrm{CO}_{2}$ from a mantle source as supported by the carbon isotopic signature of $\mathrm{CO}_{2}$ in fluid inclusions (Jackson et al. 1988; Vry et al. 1988) and the $\delta^{13} \mathrm{C}$ values of epigenetic graphite, as previously discussed. Thus, externally derived $\mathrm{CO}_{2}$-rich fluids in granulite terranes provide a vector to transport deep-seated carbon to the crust, and graphite veins represent the evidence of that process.

\section{Mechanisms of graphite deposition}

The precipitation of graphite in granulites can be the result of (a) cooling of a C-O-H fluid (Fig. 9; Cesare 1995; Pasteris 1999; Huizenga 2011), (b) the consumption of $\mathrm{H}_{2} \mathrm{O}$ in a $\mathrm{C}-\mathrm{O}-\mathrm{H}$ fluid so that it becomes carbon saturated, and (c) the infiltration of externally derived $\mathrm{CO}_{2}$ into relatively reduced rocks (Glassley 1982; Lamb and Valley 1984).

Graphite precipitation from a cooling fluid phase is caused by the reduction of the carbon solubility in a $\mathrm{C}-\mathrm{O}-\mathrm{H}$ fluid with decreasing temperature (e.g., Cesare 1995; Pasteris 1999; Huizenga 2011). Such a process can either occur under conditions of redox equilibrium (Selverstone 2005; Huizenga 2011) or redox disequilibrium (e.g., Cesare 1995; Luque et al. 1998; Huizenga 2011) between the fluid and the hostrock (i.e., the fluid $\mathrm{fO}_{2}$ is internally buffered). For fluid-rock redox equilibrium, the fluid $\mathrm{fO}_{2}$ is constrained by redox reactions within the rock. In such a scenario the temperature range at which cooling can result in graphite precipitation depends on $\mathrm{fO}_{2}$. If $\mathrm{fO}_{2}$ is buffered by $\mathrm{FMQ}$, graphite precipitation is possible during cooling at $T>400{ }^{\circ} \mathrm{C}$ (Fig. 10a) whereas if $\mathrm{fO}_{2}$ is one $\log _{10}$ unit lower (FMQ-1), graphite can only precipitate during cooling at $T>600{ }^{\circ} \mathrm{C}$ (Fig. 10b). Also, the relative $\mathrm{H}_{2} \mathrm{O}$ content of the fluid phase will increase because the graphite precipitation reaction during cooling is $\mathrm{CO}_{2}+2 \mathrm{H}_{2} \rightarrow \mathrm{C}+2 \mathrm{H}_{2} \mathrm{O}$ (Huizenga 2011).

Graphite precipitation during cooling under conditions of fluid-rock disequilibrium has been suggested by Cesare (1995), Luque et al. (1998) and Pasteris (1999), among others. Here, graphite precipitates according to the reaction $\mathrm{CO}_{2}+\mathrm{CH}_{4} \rightarrow 2 \mathrm{C}+2 \mathrm{H}_{2} \mathrm{O}$. Consequently, the fluid atomic $\mathrm{H} /$ $\mathrm{O}$ ratio remains constant while the $\mathrm{H}_{2} \mathrm{O}$ content in the fluid phase and the fluid $\mathrm{fO}_{2}$ increase (Fig. 10c; Huizenga 2011). The greatest decline in the fluid $\mathrm{C}$-content with decreasing temperature will be for a fluid in which the $\mathrm{H} / \mathrm{O}$ atomic ratio is 2 (e.g., Pasteris 1999; Huizenga 2011; Fig. 10c). It is important to note that the $\mathrm{H}_{2} \mathrm{O}$ content in the fluid phase will increase, irrespective of whether it occurs under conditions of fluid-rock redox equilibrium or not, during graphite precipitation.

The consumption of $\mathrm{H}_{2} \mathrm{O}$ from an $\mathrm{H}_{2} \mathrm{O}$-rich $\mathrm{C}-\mathrm{O}-\mathrm{H}$ fluid by hydration reactions causes the fluid to become saturated with respect to carbon (Fig. 10d). These hydration reactions likely occur at relatively low temperatures as the $\mathrm{H}_{2} \mathrm{O}$-activity in a C-O-H fluid is $<1$ (e.g., Newton 1995). Under isothermal conditions, it is likely that the extent of the hydration reactions is limited due to the systematic decrease of the $\mathrm{H}_{2} \mathrm{O}$ mole fraction in the $\mathrm{C}-\mathrm{O}-\mathrm{H}$ fluid phase as hydration reactions progress. In that case, significant graphite precipitation can only occur if there is a continuous (external) supply of $\mathrm{C}-\mathrm{O}-\mathrm{H}$ fluids. Alternatively, if hydration occurs during cooling the $\mathrm{H}_{2} \mathrm{O}$ content of the fluid phase will not decrease as much because the $\mathrm{H}_{2} \mathrm{O}$ content will increase as a result of coolingrelated graphite precipitation as explained above. In other words, $\mathrm{H}_{2} \mathrm{O}$ removal by hydration reactions and coolingrelated graphite precipitation will likely occur at the same time because of this positive feedback. The composition of fluid inclusions in quartz associated with graphite in the vein deposits from Sri Lanka seems to support this contention (Fig. 11).

Isobaric-isothermal infiltration of $\mathrm{CO}_{2}$ into relatively reduced rocks will cause graphite to precipitate according to the reaction $\mathrm{CO}_{2} \rightarrow \mathrm{C}+\mathrm{O}_{2}$ (Glassley 1982; Lamb and Valley 1984) (Fig. 10a). This process is driven by the $\mathrm{fO}_{2}$ difference between the fluid phase and the host-rock. Consequently, the amount of graphite that can precipitate depends on the oxygen buffering capacity of the host-rock, i.e., the ability of the rock to absorb the oxygen released by $\mathrm{CO}_{2}$-reduction while maintaining $\mathrm{fO}_{2}$ disequilibrium between the fluid phase and the host-rock. However, it is expected that a high fluid-rock ratio will quickly exhaust the oxygen buffering capacity of the host-rock, in which case the host-rock $\mathrm{fO}_{2}$ will increase and redox equilibrium with the fluid phase is reached. A high 

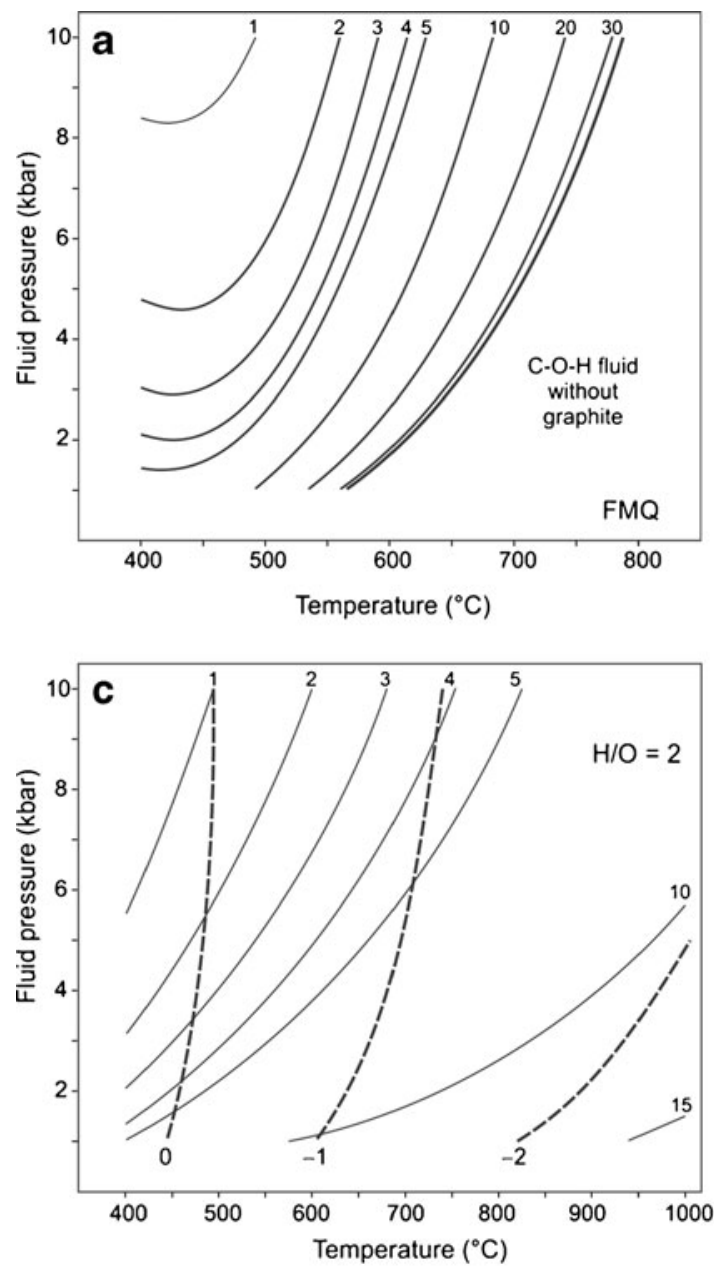

Fig. 10 a $P-T$ diagram showing the carbon isopleths (in mol.\%) of a carbon-saturated fluid of which $f \mathrm{O}_{2}$ of the fluid phase is fixed by that of the host rock (FMQ). b Same as A but for a fluid phase of which $\mathrm{fO}_{2}$ is one $\log _{10}$ unit below that of FMQ (FMQ-1). Note that graphite precipitation can only occur at $T>\sim 600^{\circ} \mathrm{C}$. At $T<\sim 600^{\circ} \mathrm{C}$ cooling will result in graphite consumption as the fluid carbon content is increasing with decreasing temperature. c $P-T$ diagram showing the carbon isopleths (in mol.\%) of a carbon-saturated fluid of an internally buffered fluid with an atomic H/O ratio of 2 (indicated as a solid square in Fig. 10d). Dashed

fluid-rock ratio would thus limit the amount of graphite that can precipitate (Huizenga and Touret 2012).

To summarize, the most efficient mechanism of graphite precipitation from a fluid phase is cooling combined with hydration reactions. The positive feedback between these processes will lead to significant amounts of graphite to be precipitated. This also implies that the graphite should postdate granulite metamorphism, which is in agreement with field observations of crosscutting graphite veins.

Graphite precipitation as a result of $\mathrm{CO}_{2}$-rich fluid infiltration into a relatively reduced rock at peak $P-T$ conditions is also a possibility, but not supported by field evidence. Also, graphite precipitation in this manner can only occur if redox disequilibrium between the fluid phase and host-rock can be maintained.
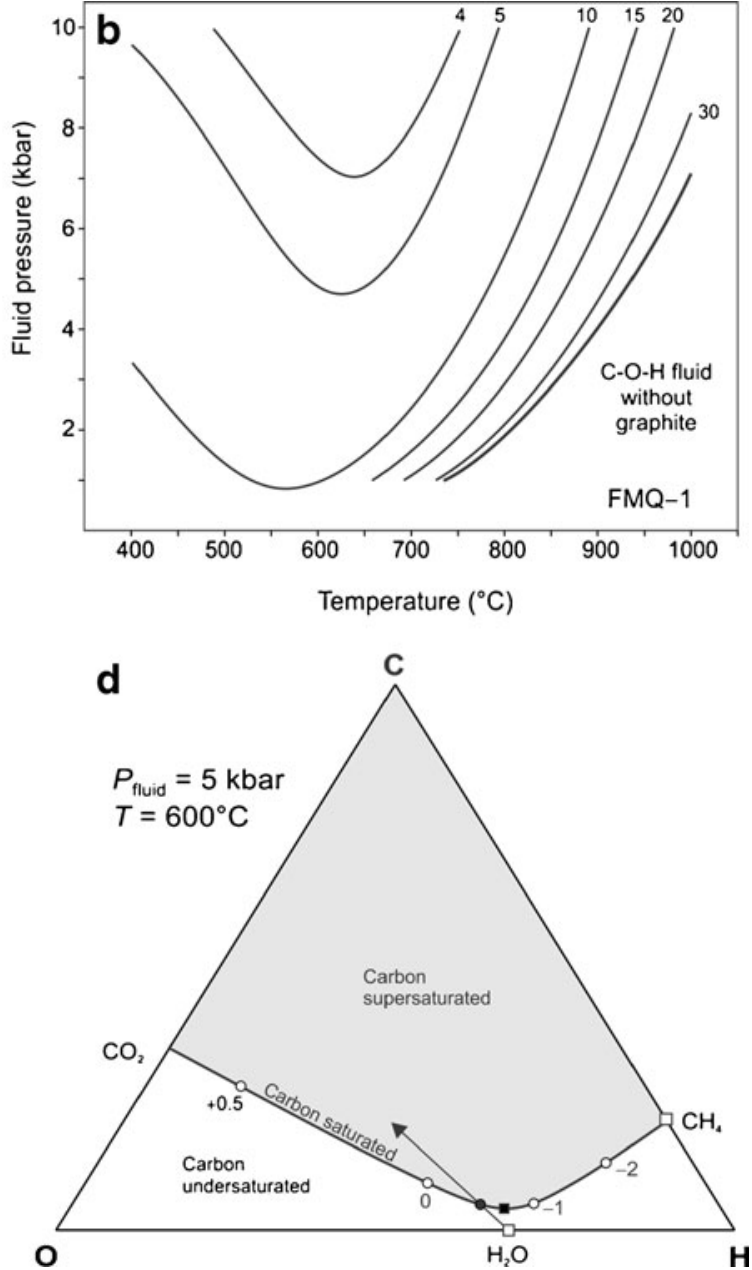

lines iso- $\mathrm{fO}_{2}$ lines relative to $\mathrm{fO}_{2}$ fixed by $\mathrm{FMQ}$. $\mathbf{d}$ Isobaric-isothermal ternary $\mathrm{C}-\mathrm{O}-\mathrm{H}$ diagram illustrating the compositional variation of a carbon saturated fluid (solid line) with changing $\mathrm{fO}_{2}$ (open circles), expressed in $\log _{10}$ units relative to $\mathrm{fO}_{2}$ fixed by the FMQ. Fields of carbon saturation (grey area) and carbon undersaturation (white area) are indicated. Consumption of $\mathrm{H}_{2} \mathrm{O}$ from a carbon-saturated $\mathrm{H}_{2} \mathrm{O}-\mathrm{CO}_{2}$ fluid phase (solid circle) will result in a carbon-saturated fluid (arrow). Solid square fluid with an atomic H/O ratio of 2

Igneous-hosted deposits

\section{Origin of carbon}

On the basis of the stable carbon isotope ratios of graphite from vein deposits and occurrences hosted by igneous rocks two main groups can be discriminated. The first group of occurrences would include those in which graphite is derived from primary mantle carbon. The second group would correspond to the occurrences in which carbon in the magma results from the assimilation of carbonaceous and/or carbonate material at crustal levels. An intermediate situation in which the primary carbon content of the magma is increased by subsequent assimilation is also possible. The examples of vein 


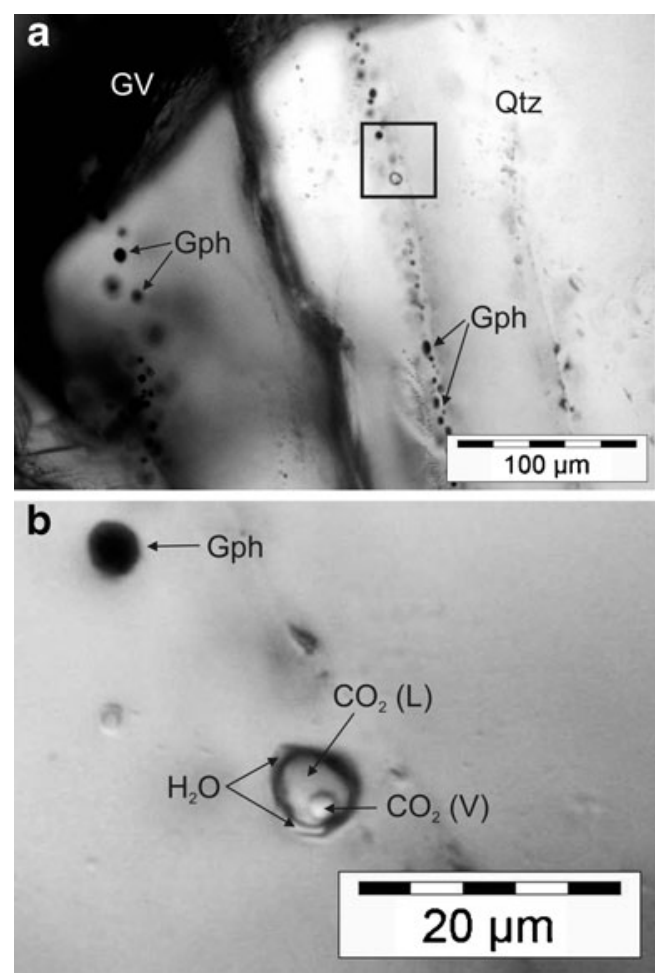

Fig. 11 a Trail of fluid inclusions within quartz (Qtz) associated with a graphite vein $(\mathrm{GV})$ from Bogala mine (Sri Lanka). Note the coexistence of $\mathrm{CO}_{2}-\mathrm{H}_{2} \mathrm{O}$ inclusions along with graphite-bearing inclusions ( $\left.\mathrm{Gph}\right)$. b Detail of the box-marked area in $\mathbf{a}$, showing a fluid inclusion containing $\mathrm{CO}_{2}(\mathrm{~V})-\mathrm{CO}_{2}(\mathrm{~L})-\mathrm{H}_{2} \mathrm{O}(\mathrm{L})$ at room temperature

deposits selected for this review cover the whole spectrum of possible carbon sources in igneous rocks (Fig. 9).

In the Borrowdale deposit, the low $\delta^{13} \mathrm{C}$ values of graphite support a biogenic origin of carbon. The volcanic host rocks of the Borrowdale Volcanic Group show field, mineralogical, and geochemical evidence of assimilation of metapelitic material from the underlying Skiddaw Group (Ortega et al. 2010). The process of assimilation of carbonaceous materials increases the carbon content of the magma and appears to play a key role in the formation of many graphite deposits hosted by igneous rocks as recently reported by Luque et al. (2012a) for graphite mineralization in volcanic settings and by Chukhrov et al. (1984) for vein graphite in nepheline syenites from the Botogol massif.

Considering the bulk isotopic values of graphite in the vein deposits of the Serranía de Ronda and Beni Bousera, the derivation of graphite solely from typical mantle carbon can be disregarded (Crespo et al. 2006a). Carbon in the parental magma was in the form of $\mathrm{CO}_{2}$ and if graphite was formed from carbon with the typical mantle signature $\left(\delta^{13} \mathrm{C}=-7 \%\right.$ o and at temperatures estimated to be close to $800{ }^{\circ} \mathrm{C}$, then the lightest graphite that could be formed would have a $\delta^{13} \mathrm{C}$ value of approximately $-12 \%$ (Crespo et al. 2006a). However, significantly lower $\delta^{13} \mathrm{C}$ values have been reported (Luque et al. 1992; Crespo et al. 2006a) and, therefore, a source of light carbon should be involved in the formation of these graphite deposits. In addition, the isotopically heavy cubic-shaped cores of some graphite aggregates would also require an isotopically heavier source than mantle carbon. Thus, it is proposed that biogenic, isotopically light crustal carbon was recycled during subduction of the lithosphere into the mantle. This assertion is supported by the presence of graphitized diamonds (with $\delta^{13} \mathrm{C}$ ranging from $-16.4 \%$ to $-27.6 \%$; Pearson et al. 1991) within some garnet pyroxenites both in the Beni Bousera and Ronda peridotites. These graphite-bearing garnet pyroxenites have been interpreted as the result of the high pressure metamorphism of the subducted oceanic crust and kerogen-rich sediments into the mantle (Crespo et al. 2006a; El Atrassi et al. 2011). On the other hand, the high $\delta^{13} \mathrm{C}$ values found in the cores of former diamonds in some graphite aggregates have been considered as resulting from the incorporation of subducting sea floor carbonate into the mantle, possibly in the form of hydrothermal calcite veins in the oceanic crust (Crespo et al. 2006a). The isotopically zoned nodule-like graphite aggregates, with heavy cores and progressively lighter to the outer parts, would have been therefore formed through the reaction of the light (biogenic) carbon in the melts with relicts of ${ }^{13} \mathrm{C}$-enriched graphitized diamonds (originally derived from hydrothermal calcite). Thus, the carbon isotopic study of graphite in the vein deposits of Beni Bousera and Serranía de Ronda probably indicate an early process of carbon assimilation in the mantle, but preserving the original biogenic and carbonate isotopic signatures.

\section{Mechanisms of carbon mobilization}

The graphite vein deposit in the andesite and diorite rocks of Borrowdale and the deposits in the ultramafic rocks of the Serranía de Ronda and Beni Bousera represent the two extreme situations of carbon mobilization in igneous rocks. Petrographic and mineralogical evidence at Borrowdale support carbon transport as carbonic species dissolved in an aqueous fluid, whereas textural features and mineral assemblages in the deposits hosted by ultramafic rocks point to carbon dissolution in a melt.

At Borrowdale carbon was transported as $\mathrm{CO}_{2}$ and $\mathrm{CH}_{4}$ in aqueous fluids as shown by fluid inclusion studies of quartz fragments associated with the graphite in the deposit (Ortega et al. 2010). The crystallization of the primary anhydrous mineral assemblage (clinopyroxene, orthopyroxene, and plagioclase) of the diorite host-rock caused the residual magma to become enriched in volatiles leading to an overpressured regime. Thus, the expansion of the volatiles triggered the upwards movement of andesitic and dioritic rocks and/or melt, quartz fragments, and a supercritical carbon-rich fluid that resulted in the formation of the breccia pipe bodies. Graphite precipitated during flow along these structures, as evidenced by the textural relationships between graphite and quartz 
fragments in the pipes. The quartz fragments contain abundant two-phase gas-rich inclusions, composed of a mixture of $\mathrm{H}_{2} \mathrm{O}$, $\mathrm{CO}_{2}$, and $\mathrm{CH}_{4}$. These are secondary inclusions which represent the earliest fluids circulating during brecciation of the quartz and the transport of the fragments upwards within the breccia pipes. Four types of fluid inclusions have been distinguished on the basis of microthermometric and Raman data. The compositional trend for the different types of fluid inclusions is consistent with an overall fluid evolution characterized by: (a) depletion in carbonic species (mainly $\mathrm{CO}_{2}$ ) becasuse of precipitation of graphite and (b) progressive decrease in the $\mathrm{XCO}_{2} /\left(\mathrm{XCO}_{2}+\mathrm{CH}_{4}\right)$ ratio (Ortega et al. 2010). The composition of the early mineralizing fluid in the secondary inclusions is compatible with a calculated carbonsaturated fluid at the mineralizing PT conditions of 2-3 kbar and $500{ }^{\circ} \mathrm{C}$, assuming that $\mathrm{fO}_{2}$ is buffered at the FMQ equilibrium.

At Serranía de Ronda and Beni Bousera it is assumed that asthenospheric-derived melts originated the partial melting of peridotites and carbon-bearing (originally diamond-bearing) pyroxenites, thus incorporating carbon into the magmas, and eventually these magmas rose up to form the ultramafic rocks outcropping in the Betic-Rifean orogenic belt. The incompatible behaviour of carbon in the mantle-derived magmas would have caused its concentration in residual sulphide-rich melts (Crespo et al. 2006a). These residual melts concentrated therefore the volatile components (mainly $\mathrm{CO}_{2}$ and $\mathrm{H}_{2} \mathrm{O}$ ), as well as $\mathrm{S}$, As, and chalcophile elements, that were transported along fractures.

\section{Mechanisms of graphite deposition}

The mechanisms involved in graphite precipitation from carbonbearing fluids are well documented in the literature (see Luque et al. 1998, and Huizenga 2011, for comprehensive reviews). Compared with fluids in granulite rocks, in most of the igneoushosted occurrences graphite deposition occurred from fluids containing both $\mathrm{CO}_{2}$ and $\mathrm{CH}_{4}$ as carbon species. This situation is especially well illustrated in the Borrowdale deposit.

As previously mentioned, there are small isotopic variations in the Borrowdale graphite both within individual nodules and between nodules collected at different places of the pipe. This means that only minor changes in temperature, bulk chemical composition of the fluid, and oxygen fugacity took place during the mineralizing process, since these are the main factors controlling graphite deposition from fluids (Huizenga 2011). Pervasive propylitic alteration of the host rocks was coeval with graphite mineralization at Borrowdale. Removal of water from the fluid would lead to a relative enrichment of carbon in the residual fluid, thus promoting saturation and, finally, graphite precipitation (Fig. 10d). In addition, small fluctuations in the $\mathrm{XH}_{2} \mathrm{O}$ of the fluids as the hydration reactions proceeded could be responsible for the observed isotopic variation within the graphite nodules in the breccia pipe (Barrenechea et al. 2009). Microscale SIMS analysis of the different graphite morphologies reveals that within the main mineralized breccia pipe-like body, cryptocrystalline graphite is lighter than flaky graphite. Textural evidence supports that cryptocrystalline graphite crystallized earlier than flaky graphite from a supersaturated fluid. Thus, the $\delta^{13} \mathrm{C}$ data of the different graphite morphologies are consistent with the composition and evolution of the mineralizing fluids inferred from fluid inclusion data, which indicate a progressive loss of $\mathrm{CO}_{2}$. According to fluid inclusion data, the dominant graphite precipitating reaction at this main stage of graphite formation in the deposit was $\mathrm{CO}_{2} \rightarrow \mathrm{C}+\mathrm{O}_{2}$ (Ortega et al. 2010). Late chlorite-graphite veins represent a different stage of the mineralizing process. In these veins, the morphologies corresponding to higher carbon supersaturation (i.e., spherulites) are isotopically heavier than those formed under lower carbon supersaturation conditions (i.e., flakes). This agrees with the progressively lower carbon supersaturation in the fluid phase. The $\mathrm{CH}_{4}$-enriched fluids at this stage of the mineralizing event produced the successive precipitation of isotopically lighter graphite morphologies following the reaction $\mathrm{CH}_{4}+\mathrm{O}_{2} \rightarrow \mathrm{C}+$ $2 \mathrm{H}_{2} \mathrm{O}$ (Barrenechea et al. 2009).

The magmatic graphite-sulfide vein deposits at Serranía de Ronda and Beni Bousera imply graphite crystallization from a melt. According to Crespo et al. (2006a), the formation of the different magmatic ores in these ultramafic rocks can be considered as an example of extreme fractional crystallization in an immiscible sulfide melt. This melt probably collected the most incompatible elements including carbon (Fig. 9). However, the mechanisms responsible for graphite crystallization from these carbon- and sulfide-rich melts still remain unclear. It is well known that intrinsic melt properties (temperature, pressure, $\mathrm{fO}_{2}, \mathrm{SiO}_{2}$ content, and $\mathrm{FeO}$ content) affect sulfur solubility in silicate melts (e.g., Mavrogenes and O’Neill 1999). However, carbon solubility is more poorly known, but $\mathrm{CO}_{2}$ solubility increases with increasing pressure, oxygen fugacity and magma alkalinity (Lowenstern 2001). In sulfide-rich magmas, low solubility of carbon in pyrrhotite and pentlandite melts has been reported (Palyanov et al. 2006). Recently, Tomkins et al. (2012) have related sulfide solubility to the assimilation of graphite-bearing rocks by mafic magmas in an island arc setting. Graphite would act as an oxygen buffer, reducing $\mathrm{fO}_{2}$ in the magma. Because sulfate has a higher solubility than sulphide in a melt phase, these reducing conditions would have caused separation of an immiscible sulfide-rich melt by conversion of dissolved sulfate into sulfide. The mineral paragenesis (pyrrhotite+chalcopyrite + pentlandite + graphite) described by these authors is similar to that found in the deposits from Serranía de Ronda and Beni Bousera (Fig. 6b). In addition to reduction-induced sulfide saturation in the melt, it is also known that sulfides catalyze the crystallization of graphite (Luque et al. 1998, and 
references therein). Thus, the crystallization of both sulfides and graphite from the carbon- and sulfide-rich residual melts could be mutually favoured.

\section{Economic significance}

The physical and chemical properties of both natural and synthetic graphite are used in a large number of industrial applications. Both synthetic and natural graphite is used in these applications. Interestingly, graphite has properties of both metals and nonmetals. The metallic properties include electrical and thermal conductivity. The nonmetallic properties include high-thermal resistance, chemical inertness, and lubricity. Thus, a single property or some combination of them is used in the different applications, the size of the graphite crystal being an additional feature for the end use. The size of graphite flakes is commercially very important since flake graphite can be four times worth the price of amorphous graphite, and lump graphite from vein deposits has even a higher value (Olson 2011). It is important to note that while small flake graphite can be manufactured from large flake, the reverse cannot be produced.

The majority of the usage of graphite today is in refractory applications, which consumes about $35 \%$ of the graphite supply. Other major uses of graphite include lubricants, steelmaking, expanded graphite, brake linings and foundry facings. There is also a variety of other industrial uses which account for the remainder graphite consumption, including zinc-carbon, zinc-chloride, and alkaline batteries, electric motor brushes and pencil leads (Olson 2011).

In addition to these traditional uses of graphite, many new applications in advanced technologies are being developed. Relevant new applications are those for Li-ion batteries now used widely in the consumer electronics industry in devices like mobile telephones, laptop and tablet computers, media players, and for fuel cells. These advanced technology products require high-purity natural flake graphite (Olson 2011), although synthetic graphite may also offer an alternative promise in the future (Moores 2010). A substantial increase in the production of hybrid and electric vehicles is expected, which in turn will likely increase the demand for high-purity graphite to be used in fuel cells and rechargeable batteries (Scrosati and Garche 2010). In particular, Li-ion batteries and fuel cells are expected to consume as much graphite as all other applications combined (United States Geological Survey 2012). Current graphite demand for Li-ion batteries is about 30,000 tons per year and is expected to grow about $20-30 \%$ annually.

Surprisingly, lump graphite mined from vein deposits is mainly used for lubricant and refractory applications (Olson 2011). No applications to new developing technologies are reported. However, lump graphite has the highest carbon contents of all commercial types of graphite and it is characterized by a high degree of crystallinity that equals or is even higher than that of flake graphite mined from syngenetic deposits hosted by high-grade metamorphic rocks. Therefore, it is proposed here that vein graphite can be an alternative to flake graphite for these new and high valueadded applications. Recent experiments have proved the suitability of vein graphite in some new application fields, like that of Li-ion batteries (Balasooriya et al. 2007). That study concluded that the electrochemical properties of vein graphite from Sri Lanka can further be enhanced by simple ball-milling or chemical treatments. Kumarasinghe et al. (2013) report the fabrication of carbon nanomaterials such as flexible multilayer graphene oxide membrane and carbon nanotubes from vein graphite. Advances in thermal technology and acid-leaching techniques that enable the production of higher purity graphite are likely to lead to development of new applications for graphite in high-technology fields (United States Geological Survey 2012).

In addition to the use of vein graphite in new technologies, geological and mineralogical data from this type of deposits also provide interesting potential applications to the field of graphite synthesis. Currently, synthetic graphite is obtained from petroleum coke through a very expensive high-temperature heating process. Geological and mineralogical evidence from vein deposits point to the possibility of graphite synthesis from carbonbearing fluids. Luque et al. (2009) demonstrated that under appropriate pressure-temperature-composition, highly crystalline graphite can precipitate at moderate temperature $\left(\sim 500^{\circ} \mathrm{C}\right)$ from fluids containing $\mathrm{CO}_{2}$ and $\mathrm{CH}_{4}$.

\section{Conclusions}

Vein graphite deposits are associated with both granulitefacies metamorphic and igneous rocks. The deposits in each geological setting are not restricted to any specific lithology. The deposits are structurally controlled, cross-cutting their host rocks and, in most cases, hydraulic fracturing is involved in their formation. Graphite veins in granulite rocks are usually monomineralic, whereas in igneous rocks graphite can be associated with a variety of hydrous minerals or magmatic sulfides depending if they were formed from aqueous fluids or from carbon-rich melts. The mineral association also depends on the mechanisms operating during graphite deposition. Independently of the geological setting, graphite from vein deposits displays large crystal size (lump graphite in commercial terms) and it is highly crystalline. In addition, vein graphite has higher carbon content than graphite in any syngenetic deposit within metamorphic rocks.

The source of carbon differs from granulite-hosted to igneoushosted deposits. Carbon in granulites has a sublithospheric source or, in some localities, formed by decarbonation reactions 
of carbonate-bearing lithologies. Graphite in igneous rocks mainly derives from the assimilation of rocks containing organic matter by the magmas. Because of the low solubility of carbon in silicate magmas, immiscibility results in the formation of carbon-rich magmas or fluids. Carbon is transported as $\mathrm{CO}_{2}$ and/or $\mathrm{CH}_{4}$ in supercritical aqueous fluids, depending on $f \mathrm{O}_{2}$, both in granulites and in igneous rocks along fracture systems. The most efficient mechanism responsible for graphite deposition in granulite-facies rocks is cooling combined with water consumption by reaction with wallrocks. In igneous-hosted deposits, cooling of the melt or fluid and water consumption from the fluids are the main causes of graphite deposition. Water consumption from $\mathrm{C}-$ $\mathrm{O}-\mathrm{H}$ fluids in igneous rocks is usually related to hydration reactions of the host-rocks leading to the formation of hydrous minerals with graphite in the veins.

On the basis of its high purity and crystallinity, graphite from vein deposits could be used in new technological applications, especially in Li-ion batteries and fuel cells. The mechanisms of precipitation of graphite from $\mathrm{C}-\mathrm{O}-\mathrm{H}$ fluids at moderate temperature may provide an alternative method for industrial manufacturing of high purity, highly crystalline synthetic graphite.

Acknowledgments This paper is a contribution from project CGL2010-16008 of the Spanish Ministry of Economy and Competitivity. The authors acknowledge constructive criticisms of two anonymous referees as well as helpful suggestions by A. Gilg (Associate Editor) and G. Beaudoin (Editor in Chief) that helped to improve the paper. We thank J.L. González (Instituto de Geociencias) for the excellent photographic artwork.

\section{References}

Acharya BC, Dash B (1984) Graphite in Eastern Ghats Precambrian migmatites, Orissa, India. Trans R Soc Edinb Earth Sci 75:391-406

Acharya BC, Rao DS (1998) Graphite in Eastern Ghat complex of Orissa. Geol Survey India Spec Publ 44:190-200

Baiju KR, Nambiar CG, Jadhav GN, Kagi H, Satish-Kumar M (2009) Low-density $\mathrm{CO}_{2}$-rich fluid inclusions from charnockites of southwestern Madurai Granulite Block, southern India; implications on graphite mineralization. J Asian Earth Sci 8:332-340

Balan A, Kumar R, Boukhicha M, Beyssac O, Bouillard J-C, Taverna D, Sacks W, Marangolo M, Lacaze E, Gohler R, Escoffier W, Poumirol J-M, Shukla A (2010) Anodic bonded graphene. J Phys D Appl Phys 43:374013

Balasooriya NWB, Touzain P, Baranayake WSK (2007) Capacity improvement of mechanically and chemically treated Sri Lanka natural graphite as an anode material in Li-ion batteries. Ionics 13:305-309

Barrenechea JF, Luque FJ, Millward D, Ortega L, Beyssac O, Rodas M (2009) Graphite morphologies from the Borrowdale deposit (NW England, UK): Raman and SIMS data. Contrib Mineral Petrol 158: $37-51$

Bastin ES (1912) The graphite deposits of Ceylon. A review of present knowledge with a description of a similar graphite deposit near Dillon, Montana. Econ Geol 7:449-473
Beyssac O, Goffé B, Chopin C, Rouzaud J-N (2002) Raman spectra of carbonaceous materials in metasediments: a new geothermometer. $\mathrm{J}$ Metamorph Geol 20:859-871

Binu-Lal SS, Kehelpannala KW, Satish-Kumar M, Wada H (2003) Multistage graphite precipitation through protracted fluid flow in sheared metagranitoid, Digana, Sri Lanka: evidence from stable isotopes. Chem Geol 197:253-270

Cameron EN, Weis L (1960) Strategic graphite: a survey. Geol Surv Bull 1082-E:201-321

Cesare B (1995) Graphite precipitation in C-O-H fluid inclusions: closedsystem compositional and density changes, and thermobarometric implications. Contrib Mineral Petrol 122:25-33

Cesare B, Meli S, Nodari L, Russo U (2005) $\mathrm{Fe}^{3+}$ reduction during biotite melting in graphitic metapelites: another origin of $\mathrm{CO}_{2}$ in granulites. Contrib Mineral Petrol 149:129-140

Chukhrov F, Ermilova L, Hosik L (1984) On the isotopic composition of carbon in epigenetic graphites. In: Wauschkuhn A et al (eds) Syngenesis and Epigenesis in the Formation of Mineral Deposits. Springer-Verlag, Berlin-Heidelberg, pp 130-137

Crespo E, Luque FJ, Rodas M (2003) Alteración de la cristalinidad del grafito por cizalla simple: comparación entre procesos experimentales y naturales. Bol Soc Española Min 26:137-153

Crespo E, Luque J, Fernández-Rodríguez C, Rodas M, Díaz-Azpiroz M, Fernández-Caliani JC, Barrenechea JF (2004) Significance of graphite occurrences in the Aracena Metamorphic Belt, Iberian Massif. Geol Mag 141:687-697

Crespo E, Luque FJ, Barrenechea JF, Rodas M (2005) Mechanical graphite transport in fault zones and the formation of graphite veins. Mineral Mag 69:463-470

Crespo E, Luque FJ, Rodas M, Wada H, Gervilla F (2006a) Graphite-sulfide deposits in Ronda and Beni Bousera peridotites (Spain and Morocco) and the origin of carbon in mantle-derived rocks. Gondwana Res 9: 279-290

Crespo E, Luque FJ, Barrenechea JF, Rodas M (2006b) Influence of grinding on graphite crystallinity from experimental and natural data: implications for graphite thermometry and sample preparation. Mineral Mag 70:697-707

Crossley P (2000) Graphite: High-tech supply sharpens up. Industrial Minerals 398:31-47

Dinalankara DMSK, Dissanayake CB (1988) The geological setting of some major graphite deposits of Sri Lanka. J Geol Soc Sri Lanka 1: $18-25$

Dissanayake CB (1981) The origin of graphite of Sri Lanka. Org Geochem 3:1-7

Dissanayake CB (1986) The origin of vein graphite of Sri Lanka: biogenic or abiogenic? L.J.D. Fernando Felicitation Volume, Geol Soc Sri Lanka, Spec Publ:131-140

Dissanayake CB (1994) Origin of vein graphite in high-grade metamorphic terrains. Role of organic matter and sediment subduction. Miner Deposita 29:57-67

Dissanayake CB, Chandrajith R (1999) Sri Lanka-Madagascar Gondwana linkage: Evidence for a Pan-African mineral belt. J Geophys Res 10:223-235

Dobner A, Graf W, Hahn-Weinheimer P, Hirner A (1978) Stable carbon isotopes of graphite from Bogala mine, Sri Lanka. Lithos 11:251255

Duke EF, Galbreath KC, Trusty KJ (1990) Fluid inclusion and carbon isotope studies of quartz-graphite veins, Black Hills, South Dakota, and Ruby Range, Montana. Geochim Cosmochim Acta 54:683-698

El Atrassi F, Brunet F, Bouybaouene M, Chopin C, Chazot G (2011) Melting textures and microdiamonds preserved in graphite pseudomorphs from the Beni Bousera peridotite massif, Morocco. Eur J Mineral 23:157-168

Erdosh G (1970) Geology of Bogala mine, Ceylon and the origin of veintype graphite. Mineral Deposita 5:375-382 
Erdosh G (1972) Abiotic carbon and the formation of graphite deposits: Discussion. Econ Geol 67:383-384

Farquhar J, Chacko T (1991) Isotopic evidence for involvement of $\mathrm{CO}_{2}-$ bearing magmas in granulite formation. Nature 354:60-63

Ford RB (1954) Occurrence and origin of the graphite deposits near Dillon, Montana. Econ Geol 49:31-43

Glassley W (1982) Fluid evolution and graphite genesis in the deep continental crust. Nature 295:229-231

Hahn-Weinheimer P, Hirner A (1981) Isotopic evidence for the origin of graphite. Geophys J Roy Astron Soc 15:9-15

Hansen EC, Janardhan AS, Newton RC, Prame WKBN, Ravindrakumar GR (1987) Arrested charnockite formation in southern India and Sri Lanka. Contrib Mineral Petrol 96:225-244

Hapuarachchi DJAC (1977) Decarbonation reactions and the origin of vein-graphite in Sri Lanka. J Nat Sci Council Sri Lanka 5: $29-32$

Hoernes S, Fiorentini E, Hoffbauer R (1994) The role of fluids in granulite-facies metamorphism as deduced from oxygen and carbon isotopic compositions. Precambrian Res 66:183198

Huizenga JM (2011) Thermodynamic modelling of a cooling C-O-H fluid-graphite system: implications for hydrothermal graphite precipitation. Mineral Deposita 46:23-33

Huizenga JM, Touret JLR (2012) Granulites, $\mathrm{CO}_{2}$ and graphite. Gondwana Res 22:799-809

Jackson DH, Mattey D, Harris NBW (1988) Carbon isotope compositions of fluid inclusions in charnockites from southern India. Nature 333:167-170

Jaszczak JA, Trinchillo D (2013) Miracle at Merelani: a remarkable occurrence of graphite, diopside, and associated minerals. Rocks \& Minerals 88:154-165

Katz MB (1987) Graphite deposits from Sri Lanka: a consequence of granulite facies metamorphism. Mineral Deposita 22:18-25

Kehelpannala KW (1999) Epigenetic vein graphite mineralization in the granulite terrain of Sri Lanka. Gondwana Res 2:654-657

Kehelpannala KW, Francis MDL (2001) Vein graphite deposits of the Kegalle District, Sri Lanka: further evidence for post-metamorphic, fluid-deposited graphite. Gondwana Res 4:655-656

Krishna Rao JSR, Malleswara Rao P (1965) Occurrence and origin of graphite in parts of Eastern Ghats, South India. Econ Geol 60:10461051

Kröner A, Williams IS (1993) Age of metamorphism in the high-grade rocks of Sri Lanka. J Geophys Res 101:513-521

Kumarasinghe AR, Samaranayake L, Bondino F, Magnano E, Kottegoda N, Carlino E, Ratnayake UN, de Alwis AAP, Karunaratne V, Amaratunga GAJ (2013) Self-assembled multilayer graphene oxide membrane and carbon nanotubes synthesized using a rare form of natural graphite. J Phys Chem C 117:9507-9519

Kwiecinska B, Petersen HI (2004) Graphite, semi-graphite, natural coke, and natural char classification-ICCP system. Internat J Coal Geol 57:99-116

Lamb W, Valley JW (1984) Metamorphism of reduced granulites in low$\mathrm{CO}_{2}$ vapour-free environment. Nature 312:56-58

Lowenstern JB (2001) Carbon dioxide in magmas and implications for hydrothermal systems. Mineral Deposita 36:490-502

Luque FJ, Rodas M, Galán E (1992) Graphite vein mineralization in the ultramafic rocks of southern Spain: Mineralogy and genetic relationships. Mineral Deposita 27:226-233

Luque FJ, Pasteris JD, Wopenka B, Rodas M, Barrenechea JF (1998) Natural fluid deposited graphite: mineralogical characteristics and mechanisms of formation. Am J Sci 298:471-498

Luque FJ, Rodas M (1999) Constraints on graphite crystallinity in some Spanish fluid-deposited occurrences from different geologic settings. Mineral Deposita 34:215-219
Luque FJ, Ortega L, Barrenechea JF, Millward D, Beyssac O, Huizenga JM (2009) Deposition of highly crystalline graphite from moderatetemperature fluids. Geology 37:275-278

Luque FJ, Ortega L, Barrenechea JF, Huizenga JM, Millward D (2012a) Key factors controlling massive graphite deposition in volcanic settings: an example of a self-organized critical system. J Geol Soc Lond 169:269-277

Luque FJ, Crespo-Feo E, Barrenechea JF, Ortega L (2012b) Carbon isotopes of graphite: implications on fluid history. Geosci Front 3: 197-207

Matsuura Y, Kehelpannala KW, Wada H (2007) Differential thermal analysis of Sri Lankan type vein graphite. Geosci Reports Shizuoka Univ 34:7-18

Mavrogenes JA, O'Neill HSC (1999) The relative effects of pressure, temperature and oxygen fugacity on the solubility of sulfide in mafic magmas. Geochim Cosmochim Acta 63:1173-1180

Mitchell CJ (1993) Industrial Minerals Laboratory Manual: Flake graphite. British Geological Survey Technical Report, WG/92/30, 31 pp

Moores S (2010) Concern over battery grade graphite supplies. Industrial Min 509:12

Newton RC (1995) Simple-system mineral reactions and high-grade metamorphic fluids. Eur J Mineral 7:861-881

Newton RC, Smith J, Windley BF (1980) Carbonic metamorphism, granulites and crustal growth. Nature 288:45-50

Olson DW (2011) Graphite. In: U.S. Geological Survey Minerals Yearbook2009. U.S. Geological Survey, Reston, Virginia, pp 32.1-32.10

Ortega L, Millward D, Luque FJ, Barrenechea JF, Beyssac O, Huizenga JM, Rodas M, Clarke SM (2010) The graphite deposit at Borrowdale (UK): a catastrophic mineralizing event associated with Ordovician magmatism. Geochim Cosmochim Acta 74:2429-2449

Palyanov YN, Borzdov YM, Khokhryakov AF, Kupriyanov IN, Sobolev N (2006) Sulfide melts-graphite interaction at HPHT conditions: implications for diamond genesis. Earth Planet Sci Lett 250:269-280

Pasteris JD (1999) Causes of the uniformly high crystallinity of graphite in large epigenetic deposits. J Metamorph Geol 17:779-787

Pearson DG, Davies GR, Nixon H, Mattey D (1991) A carbon isotope study of diamond facies pyroxenites and associated rocks from the Beni Bousera peridotite, North Morocco. J Petrol, Spec Lherzolites Issue: $175-189$

Radhika U, Santosh M (1995) A comparative study of graphite occurrences in South India, Sri Lanka and Madagascar within east Gondwana. In: Yoshida M, Santosh M, Rao AT (eds) India as a fragment of East Gondwana. Gondwana Research Group Memoir-2. Field Science Publishers, Japan, pp 143-157

Radhika U, Santosh M (1996) Shear-zone hosted graphite in southern Kerala, India: implications for $\mathrm{CO}_{2}$ infiltration. J Southeast Asian Earth Sci 14:265-273

Radhika U, Santosh M, Wada H (1995) Graphite occurrences in southern Kerala: characteristics and genesis. J Geol Soc India 45:653-666

Sajeev K, Osanai Y (2004) Ultrahigh-temperature metamorphism $\left(1150^{\circ} \mathrm{C}, 12 \mathrm{kbar}\right)$ and multi-stage evolution of $\mathrm{Mg}$-Al granulites from Central Highland Complex, Sri Lanka. J Petrol 45:1821-1844

Salotti CA, Heinrich EW, Giardini AA (1971) Abiotic carbon and the formation of graphite deposits. Econ Geol 66:929-932

Salotti CA, Heinrich EW, Giardini AA (1972) On the origin of vein graphite deposits. Econ Geol 67:384-385

Santosh M, Omori S (2008a) $\mathrm{CO}_{2}$ flushing: a plate tectonic perspective. Gondwana Res 13:86-102

Santosh M, Omori S (2008b) $\mathrm{CO}_{2}$ windows from mantle to atmosphere: models on ultrahigh-temperature metamorphism and speculations on the link with melting of snowball Earth. Gondwana Res 14:82-96

Santosh M, Wada H (1993a) Microscale isotopic zonation in graphite crystals: evidence for channelled $\mathrm{CO}_{2}$ influx in granulites. Earth Planet Sci Lett 119:19-26 
Santosh M, Wada H (1993b) A carbon isotope study of graphites from the Kerala Khondalite Belt, southern India: evidence for $\mathrm{CO}_{2}$ infiltration in granulites. J Geophys Res 101:643-651

Satish-Kumar M (2005) Graphite-bearing $\mathrm{CO}_{2}$-fluid inclusions in granulites: Insights on graphite precipitation and carbon isotope evolution. Geochim Cosmochim Acta 69:3841-3856

Santosh M, Wada H, Satish-Kumar M, Binu-Lal SS (2003) Carbon isotope "stratigraphy" in a single graphite crystal: Implications for the crystal growth mechanism of fluid-deposited graphite. Am Mineral 88:1689-1696

Satish-Kumar M, Santosh M (1998) A petrological and fluid inclusion study of calc-silicate charnockite associations from southern Kerala, India: implications for $\mathrm{CO}_{2}$ influx. Geol Mag 135:27-45

Satish-Kumar M, Yurimoto H, Itoh S, Cesare B (2011) Carbon isotope anatomy of a single graphite crystal in a metapelitic migmatite revealed by high-spatial resolution SIMS analysis. Contrib Mineral Petrol 162:821-834

Scrosati B, Garche J (2010) Lithium batteries: status, prospects and future. J Power Sources 195:2419-2430

Selverstone J (2005) Preferential embrittlement of graphitic schists during extensional unroofing in the Alps: the effect of fluid composition on rheology in low-permeability rocks. J Metamorph Geol 23: 461-470

Silva KKMW (1974) Tectonic control of graphite mineralization in Sri Lanka. Geol Mag 111:307-312

Silva KKMW (1987) Mineralization and wall-rock alteration at the Bogala graphite deposit, Bulathkohupitiya, Sri Lanka. Econ Geol $82: 1710-1722$

Sinha RK (1982) Graphite. In: Industrial Minerals. A.A. Balkema, Rotterdam, pp 237-248

Soman K, Lobzova R, Sivadas KM (1986) Geology, genetic types, and origin of graphite in South Kerala, India. Econ Geol 81:997-1002

Tadokoro H, Tsunogae T, Santosh M, Yoshimura Y (2007) First report of the spinel plus quartz assemblage from Kodaikanal in the Madurai block, southern India: Implications for ultrahigh-temperature metamorphism. Internat Geol Rev 49:1050-1068
Tomkins AG, Rebryna KC, Weinberg RF, Schaefer BF (2012) Magmatic sulfide formation by reduction of oxidized arc basalt. J Petrol 53: $1537-1567$

Touret JRL (1971) Le facies granulite en Norvege meridionale. II: Les inclusions fluids. Lithos 4:423-426

Touret JLR, Huizenga JM (2011) Fluids in granulites. In: van Reenen DD, Kramers, JD, McCourt S, Perchuk LL (eds) Origin and Evolution of Precambrian High-grade Gneiss Terranes, with Special Emphasis on the Limpopo Complex of Southern Africa. Geol Soc Am Mem 207:25-37

Touret JLR, Huizenga JM (2012) Fluid-assisted granulite metamorphism: a continental journey. Gondwana Res 21:224-235

Touzain P, Balasooriya N, Bandaranayake K, Descolas-Gros C (2010) Vein graphite from the Bogala and Kahatagaha-Kolongaha mines, Sri Lanka: a possible origin. Can Min 48:1373-1384

Tsuchiya N, Suzuki S, Chida T (1991) Origin of graphite in the Oshirabetsu gabbroic body, Hokkaido, Japan. J Miner Petrol Econ Geol 86:264-272

United States Geological Survey (2012) Graphite. In: Mineral Commodity Summaries 2012. U.S. Geological Survey, Reston, Virginia, pp 68-69

Vry J, Brown E, Valley JW, Morrison J (1988) Constraints on granulite genesis from carbon isotope composition of cordierite and graphite. Nature 332:66-68

Wada H, Santosh M (1995) Stable isotopic characterization of metamorphic fluid processes in the Kerala Khondalite Belt, South India. Mem Geol Soc India 34:161-172

Weis L, Friedman I, Gleason J (1981) The origin of epigenetic graphite: evidence from isotopes. Geochim Cosmochim Acta 45:2325-2332

Wilde SA, Dorsett-Bain H, Lennon RG (1999) Geological setting and controls on the development of graphite, sillimanite and phosphate mineralization within the Jiamusi massif: an exotic fragment of Gondwanaland located in north-eastern China? Gondwana Res 2: $21-46$

Wopenka B, Pasteris JD (1993) Structural characterization of kerogens to granulite-facies graphite: applicability of Raman microprobe spectroscopy. Am Mineral 78:533-557 